\title{
Modelling the impact of megacities on local, regional and global tropospheric ozone and the deposition of nitrogen species
}

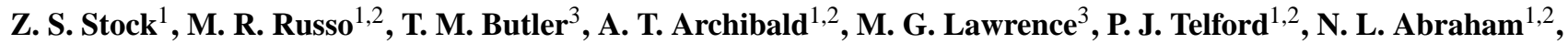 \\ and J. A. Pyle ${ }^{1,2}$ \\ ${ }^{1}$ Centre for Atmospheric Science, Department of Chemistry, University of Cambridge, Cambridge, CB2 1EW, UK \\ ${ }^{2}$ National Centre for Atmospheric Science, Department of Chemistry, University of Cambridge, Cambridge, CB2 1EW, UK \\ ${ }^{3}$ Institute for Advanced Sustainability Studies, Potsdam, Germany \\ Correspondence to: Z. S. Stock (zss21@ cam.ac.uk)
}

Received: 22 May 2013 - Published in Atmos. Chem. Phys. Discuss.: 4 July 2013

Revised: 5 November 2013 - Accepted: 22 November 2013 - Published: 17 December 2013

\begin{abstract}
We examine the effects of ozone precursor emissions from megacities on present-day air quality using the global chemistry-climate model UM-UKCA (UK Met Office Unified Model coupled to the UK Chemistry and Aerosols model). The sensitivity of megacity and regional ozone to local emissions, both from within the megacity and from surrounding regions, is important for determining air quality across many scales, which in turn is key for reducing human exposure to high levels of pollutants. We use two methods, perturbation and tagging, to quantify the impact of megacity emissions on global ozone. We also completely redistribute the anthropogenic emissions from megacities, to compare changes in local air quality going from centralised, densely populated megacities to decentralised, lower density urban areas. Focus is placed not only on how changes to megacity emissions affect regional and global $\mathrm{NO}_{\mathrm{x}}$ and $\mathrm{O}_{3}$, but also on changes to $\mathrm{NO}_{\mathrm{y}}$ deposition and to local chemical environments which are perturbed by the emission changes.

The perturbation and tagging methods show broadly similar megacity impacts on total ozone, with the perturbation method underestimating the contribution partially because it perturbs the background chemical environment. The total redistribution of megacity emissions locally shifts the chemical environment towards more $\mathrm{NO}_{\mathrm{x}}$-limited conditions in the megacities, which is more conducive to ozone production, and monthly mean surface ozone is found to increase up to $30 \%$ in megacities, depending on latitude and season. However, the displacement of emissions has little effect on the global annual ozone burden ( $0.12 \%$ change). Globally, megacity emissions are shown to contribute $\sim 3 \%$ of total $\mathrm{NO}_{\mathrm{y}}$ deposition. The changes in $\mathrm{O}_{3}, \mathrm{NO}_{\mathrm{x}}$ and $\mathrm{NO}_{\mathrm{y}}$ de-
\end{abstract}

position described here are useful for quantifying megacity impacts and for understanding the sensitivity of megacity regions to local emissions. The small global effects of the $100 \%$ redistribution carried out in this study suggest that the distribution of emissions on the local scale is unlikely to have large implications for chemistry-climate processes on the global scale.

\section{Introduction}

Over the past few decades the rise in the world's urban population has led to an increase in the number of megacities, generally defined as cities with a population of greater than 10 million. Poor air quality is a major concern for megacities, since these areas of high population density are also intense areas of air pollutant emissions (Molina and Molina, 2004; Gurjar et al., 2008). As these cities continue to grow, future changes to emissions are a concern, not only for air quality on a local scale, but also on larger scales due to the potential influence the megacities could have on surrounding environments. Precursor emissions of tropospheric ozone, a pollutant of particular concern for adverse health effects (Molina and Molina, 2004; Gurjar et al., 2010), are increasing in many developing megacities across the world, including southeastern Asia (Streets and Waldhoff, 2000; van der A et al., 2008). In more developed megacities, such as those in Europe and the United States, recent decreases in emissions noted within the megacities (Wild et al., 2012; Parrish et al., 2011; Warneke et al., 2012) suggest external pollution 
sources may now have greater influence on their air quality (Parrish et al., 2011).

Megacity emissions of nitrogen oxides $\left(\mathrm{NO}_{\mathrm{x}}=\mathrm{NO}+\mathrm{NO}_{2}\right)$ and volatile organic compounds (VOCs) are important precursors to ozone formation. Transport of these precursor species and ozone itself can be local, regional, and hemispheric (see e.g. HTAP (Hemispheric Transport of Air Pollution) 2010 and other previous studies (e.g. Wild and Akimoto, 2001; Derwent et al., 2004; Fiore et al., 2009)). Changes to urban emissions therefore have the potential to influence air quality on much larger scales, as also investigated in the recent European collaborative project MEGAPOLI (Megacities: Emissions, urban, regional and Global Atmospheric POLlution and climate effects, and Integrated tools for assessment and mitigation) (Baklanov et al., 2010), and in a number of recent modelling studies (Mayer et al., 2000; Lawrence et al., 2007; Butler and Lawrence, 2009; Fiore et al., 2009; Butler et al., 2012). Many of these studies use pure modelling approaches to assess the impact of emission changes both in perturbation and future scenarios. In this study we use a global chemistry-climate model to analyse a range of scales.

Lawrence et al. (2007) used a three-dimensional transport model to characterise the transport of inert pollution tracers away from megacities, finding large variations between the pollution potentials of different megacities. Following from this, later studies quantified the global impact of megacities on atmospheric composition and climate by using annihilation techniques (Butler and Lawrence, 2009; Folberth et al., 2012), in which a scenario where the megacity emissions are completely removed is compared with a control run in which the emissions are unaltered. Using a threedimensional global chemistry transport model, Butler and Lawrence (2009) applied this perturbation method to show that the global megacity impact on tropospheric ozone was disproportionately small compared with the amount of ozone precursor emissions from megacities.

Besides the perturbation method, tagging methodologies have been recently used in source attribution studies (e.g. Grewe, 2004; Pfister et al., 2008; Grewe et al., 2010; Emmons et al., 2012). Ozone, as a secondary pollutant, is not directly emitted and therefore cannot be directly tagged from an emission source. Previous studies have shown that source attribution can be achieved through tagging either of its precursors, VOCs (Butler et al., 2011) or $\mathrm{NO}_{\mathrm{x}}$ (Pfister et al., 2006; Brown-Steiner and Hess, 2011; Grewe et al., 2012; Emmons et al., 2012). Grewe et al. (2010) use a tagging methodology to quantify errors in the more commonly used perturbation method for source attribution, showing that these errors have the potential to be large (factor of 2).

As megacities evolve, their impact is likely to change depending on future emissions and climate. Four future RCP (Representative Concentration Pathway) emission scenarios, as considered by Butler et al. (2012), suggest that at the global scale the impact of megacities will remain small in comparison to their share of precursor emissions throughout the 21 st century. Using a methodology in which megacity emissions were redistributed, Butler et al. (2012) investigated the sensitivity of megacity air quality to emissions from outside the megacity. Redistributing $25 \%$ of megacity emissions showed that in future scenarios the megacity grid cells became less sensitive to local emissions and more sensitive to emissions from outside these grid cells.

Our overall aim here is to understand the impact of megacity emissions, particularly on tropospheric ozone. We use both modelling approaches, perturbation as well as tagging, to explore the impact of megacity emissions, using the UMUKCA global chemistry-climate model (UK Met Office Unified Model coupled to the UK Chemistry and Aerosols model). A chemical tagging scheme has been introduced into the UM-UKCA model to allow the $\mathrm{NO}_{\mathrm{x}}$ emissions from megacities to be tracked, and hence ozone produced to be attributed to the megacity source. Tagging is useful not only in determining megacity contributions to the $\mathrm{O}_{\mathrm{x}}$ budget, but also for showing the spread of influence of megacity emissions. This is the first instance where both tagging and perturbation approaches are used to assess megacity impacts.

Results using tagging are compared with the results from annihilation and redistribution scenarios. Comparing and contrasting the modelling approaches gives an appreciation of model uncertainty. For consistency, we use a similar $25 \%$ redistribution technique to Butler et al. (2012). The UMUKCA model has both interactive chemistry and a slightly higher resolution than the model used in the study of Butler et al. (2012). We also consider a more extreme, upperbound scenario in which $100 \%$ of the anthropogenic emissions from megacities are redistributed and a scenario in which megacities are intensified by a $25 \%$ increase in emissions. To understand the changes, we focus on the resulting changes to the chemical environments on megacity regional scales. At the current resolution of global models, determining the chemical regime on small megacity scales is limited by the relatively coarse model resolution, and uncertainty in the underlying emissions. For this reason we focus particularly on regional changes and the average change across megacities grouped by latitude.

Ozone is a major pollutant with important health effects, so one aspect of our study is to consider impacts on ozone exposure. Ozone exceedance days, defined here as days where the maximum 8-hourly average ozone concentration exceeds $60 \mathrm{ppb}$ (EU, 2008), are frequently considered in air quality studies to understand the impacts that ozone changes may have on population exposure (Anenberg et al., 2009, 2010; West et al., 2009b). Here, we specifically consider changes to the daily $8 \mathrm{~h}$ maximum ozone concentrations (DM8H) by calculating $8 \mathrm{~h}$ moving averages of ozone for each scenario.

We additionally investigate the impact of megacities on terrestrial ecosystems by considering nitrogen deposition. The deposition of $\mathrm{NO}_{\mathrm{y}}$ is both a source of nutrients to terrestrial ecosystems (Sanderson et al., 2008) and a source of 
carbon uptake (Holland et al., 1997), but too much nitrogen deposition can lead to negative impacts, such as eutrophication, damage to ecosystems through nitrogen saturation (Holland et al., 1997) and soil acidification (Bowman et al., 2008). Previous studies have shown changes to $\mathrm{NO}_{\mathrm{x}}$ emissions to have a significant effect on nitrogen deposition (Lamarque et al., 2005; Dentener et al., 2006; Sanderson et al., 2008; Zhang et al., 2012). Using an average from five different models, Dentener et al. (2006) show that for a current air quality legislation (CLE) scenario between 2000 and 2030 the role of climate change in increasing $\mathrm{NO}_{\mathrm{y}}$ deposition is relatively small $(+0.6 \%)$ compared to the role of emission increases $(+11 \%)$. Based on this, future increases in megacity emissions would be expected to have a large impact on $\mathrm{NO}_{\mathrm{y}}$ deposition.

In Sect. 2, we detail the model used in this study, UMUKCA, as well as the experimental design, and discuss the $\mathrm{NO}_{\mathrm{x}}$ tagging scheme implemented. In Sect. 3, results are presented from four different emissions scenarios, two of which involve the redistribution of emissions from megacities and focus on the impact this has on the local chemical regime (Sect. 3.3). The other two scenarios investigate changes to the total emissions, one in the form of an annihilation scenario, the other an enhancement of megacity emissions. Similar analyses are performed for all scenarios, including analysis of total column ozone changes, ozone and $\mathrm{NO}_{\mathrm{x}}$ surface changes, and changes to the chemical environments. In Sect. 3.4, we quantify ozone and peroxyacetyl nitrate (PAN) attributed to megacity emissions using the tagging method, and in Sect. 3.5 we compare the perturbation and tagging results. Different scales of impact are considered, and we calculate changes to ozone exceedance values on local scales to consider the impact of megacity emission perturbations on human exposure to ozone, and investigate impacts on $\mathrm{NO}_{\mathrm{y}}$ deposition (Sect. 4). Finally we summarise our conclusions in Sect. 5.

\section{Methodology}

\subsection{The UM-UKCA model}

Model integrations are performed using the UK Chemistry and Aerosols (UKCA) model (Telford et al., 2010; Archibald et al., 2011; O'Connor et al., 2013), coupled to an atmosphere-only version of the UK Met Office Unified Model (UM) version 7.3 (Hewitt et al., 2011). The model is configured at a base horizontal resolution of $1.875^{\circ}$ in longitude by $1.25^{\circ}$ in latitude and has 63 hybrid height levels in the vertical, with a model top at $\sim 41 \mathrm{~km}$. To produce the appropriate meteorological conditions for the year 2005 (chosen as the reference year for model runs within the MEGAPOLI project), a nudging technique is used (Telford et al., 2008), which constrains the model winds and temperature to reanalysis data from the European Centre for Medium-range
Weather Forecasts (ECMWF) ERA-Interim dataset (Berrisford et al., 2009; Dee et al., 2011). All model integrations are performed for a period of one year plus a three-year spin-up (constrained to a perpetual 2005). Sea surface temperatures and sea ice cover for the year 2005 are prescribed from the AMIP dataset (http://www-pcmdi.llnl.gov/projects/amip).

A tropospheric chemistry scheme, described in O'Connor et al. (2013), is used to represent chemical cycles of $\mathrm{O}_{x}$, $\mathrm{HO}_{\mathrm{x}}$ and $\mathrm{NO}_{\mathrm{x}}$ as well as the oxidation of $\mathrm{CO}$ and other nonmethane hydrocarbons as previously described in Zeng and Pyle (2003). The oxidation of isoprene is included by implementation of the condensed Mainz Isoprene Mechanism (MIM) as described in Pöschl et al. (2000), so that a total of 60 chemical tracers and 132 photochemical reactions are represented in the model. The parameterisations of Giannakopoulos et al. (1999) are used for both dry and wet deposition. Aerosol radiative effects are represented using the CLASSIC (Coupled Large-scale Aerosol Simulator for Studies in Climate) scheme, as described by Jones et al. (2001) and Bellouin et al. (2007), and the Fast-Jx Photolysis scheme (Neu et al., 2007; Telford et al., 2013) is used for interactive calculations of photolysis rates. Upper-boundary conditions for ozone and $\mathrm{NO}_{\mathrm{y}}$ are fixed to climatological values above $70 \mathrm{hPa}$ : ozone is constrained using the Rosenlof climatology (Dall'Amico et al., 2010) and $\mathrm{NO}_{\mathrm{y}}$ is overwritten from zonal mean values from the Cambridge 2D model (Law and Pyle, 1993a, b). Concentrations of long-lived species such as $\mathrm{CO}_{2}$, $\mathrm{CH}_{4}, \mathrm{~N}_{2} \mathrm{O}$ and CFCs are fixed to constant values representative of the year 2005. Surface emissions for the chemical species are generated from the emission dataset by Lamarque et al. (2010), as developed for the Intergovernmental Panel for Climate Change (IPCC) Fifth Assessment Report, and updated to 2005 using the RCP-8.5 scenario (Riahi et al., 2011). Isoprene emissions are taken from the POET database (Granier et al., 2005; Olivier et al., 2003) and biomass burning emissions are for the year 2005 taken from the Global Fire Emissions Database (GFED) version 3 (van der Werf et al., 2010). Other biogenic emissions, including emissions of $\mathrm{CO}, \mathrm{Me}_{2} \mathrm{CO}$ and $\mathrm{NO}$, are as described in O'Connor et al. (2013). Long-term climatologies and the IPCC A2 scenario projections are used to provide soot and sulphur emissions from biomass burning for input to the model aerosol scheme.

The current model configuration was evaluated by comparing modelled ozone with ozone concentrations from a number of datasets, including the Logan (1999) sonde data, the Southern Hemisphere Additional Ozonesondes (SHADOZ) data (Thompson et al., 2003), the European Monitoring and Evaluation Programme (EMEP) network (http://www.emep.int/) and the US Clean Air Status and Trends Network (CASTNet; http://www.epa.gov/castnet/). This analysis showed that the seasonality of ozone is captured well and the model produces present-day ozone comparable to observations and to other global models (cf. Stevenson et al., 2006), although ozone is slightly overpredicted in the Northern Hemisphere. An evaluation of the tropospheric 
Table 1. A summary of simulations performed in this study. Each simulation is run for one year.

\begin{tabular}{llc}
\hline Scenario & Description & $\begin{array}{c}\text { Total global } \\
\text { emissions altered }\end{array}$ \\
\hline $\begin{array}{l}\text { Base } \\
100 \% \text { redistribution }\end{array}$ & $\begin{array}{l}\text { Control run with the original emissions dataset anthropogenic emissions are removed from } \\
\text { megacity grid cells and redistributed into the } \\
\text { country to which the megacity belongs }\end{array}$ & no \\
$25 \%$ redistribution & $\begin{array}{l}25 \% \text { of anthropogenic emissions are removed from } \\
\text { megacity grid cells and redistributed into the country } \\
\text { to which the megacity belongs } \\
\text { All anthropogenic emissions are completely removed } \\
\text { from megacity grid cells } \\
\text { Anthropogenic emissions are increased by 25\% in all } \\
\text { megacity grid cells }\end{array}$ & no \\
& yes & yes \\
\hline
\end{tabular}

chemistry scheme can be found in Telford et al. (2013). For the present study, the effects of these slight ozone biases are minimised by the experimental design, which focuses on comparing the impact of emission perturbations between model runs containing similar underlying biases.

\subsection{Megacity mask}

In order to perform perturbation experiments of the emissions from megacities, we need to reliably identify model grid cells in which the megacities are located. Previously different approaches have been used, both for identifying urban grid cells (Mayer et al., 2000) and for creating a megacity mask at $1^{\circ} \times 1^{\circ}$ resolution (Butler et al., 2008). In this study we use a combination of the above-mentioned methods, coupled to the RCP-8.5 emissions dataset at a higher resolution of $0.5^{\circ} \times 0.5^{\circ}$ to produce a more realistic megacity mask for a total of 36 megacities. This new approach, summarised below, was also used to identify megacity grid cells in a recent study by Butler et al. (2012).

Initial megacity coordinates are taken from the Collins World Atlas (Harpercollins Reference, 2008), with any grid cell surrounding these coordinates included if $\mathrm{NO}_{\mathrm{x}}$ emissions show values above a chosen threshold of $10 \mathrm{~kg}(\mathrm{~N}) \mathrm{day}^{-1} \mathrm{~km}^{-2}$. As in Butler et al. (2008), the urban agglomerations of the Po Valley and Rhine-Ruhr are included, as these regions act as similar pollution hotspots on a megacity scale. These were identified based on their definitions within the EU MEGAPOLI project (Butler et al., 2012).

\subsection{Emission scenarios}

A megacity mask, described in Sect. 2.2, was used to produce a range of megacity emission scenarios for inclusion in the model. In all the experiments, we vary only the anthropogenic component of the emissions from megacities, and the changes in emissions are applied equally across all sectors. The total magnitude of megacity anthropogenic $\mathrm{NO}_{\mathrm{x}}$ emissions in this study is $\sim 6 \mathrm{Tg} \mathrm{yr}^{-1}$. This is equal to $\sim 6 \%$ of the global total anthropogenic $\mathrm{NO}_{\mathrm{x}}$ emissions. For nonmethane VOCs (NMVOCs), the total magnitude of megacity anthropogenic emissions is $\sim 1.5 \mathrm{Tg} \mathrm{yr}^{-1}$ ( $\sim 5 \%$ of the global total anthropogenic NMVOC emissions). A total of five simulations are performed: a "base" run, using emissions from the standard dataset; an "annihilation" run, where anthropogenic emissions from megacities are totally removed; two "redistribution" runs with respectively $25 \%$ and $100 \%$ of anthropogenic emissions redistributed from megacity grid cells; and finally an "increased" emissions scenario in which megacity anthropogenic emissions are increased by $25 \%$. A list of the simulations and a brief description can be found in Table 1. All emission perturbations are applied at the $0.5^{\circ} \times 0.5^{\circ}$ resolution. The emissions are then interpolated to the UM-UKCA model resolution of $1.875^{\circ} \times 1.25^{\circ}$.

The annihilation technique was previously used in Butler and Lawrence (2009) and Butler et al. (2012), and is used here for comparison, although it is an oversimplification and can cause sharp artificial gradients on local scales. To consider regional and local scales, we employ $25 \%$ and $100 \%$ redistribution scenarios, reducing the anthropogenic emissions in megacity grid cells by respectively $25 \%$ and $100 \%$ and spreading these emissions across the country in which the megacity is located. Unlike in the annihilation scenario, emission totals remain constant for each country and globally. Finally, the increased emissions scenario considers intensification of the megacity emissions, investigating the impact of more concentrated megacity emissions on ozone in the surrounding regions. The anthropogenic emissions in the megacity grid cells are increased by $25 \%$. This leads to an increase in the global total ozone precursor emissions, with an increase in the share that megacities contribute to the total. Differences between emissions in each of the scenarios are shown in Fig. 1. 


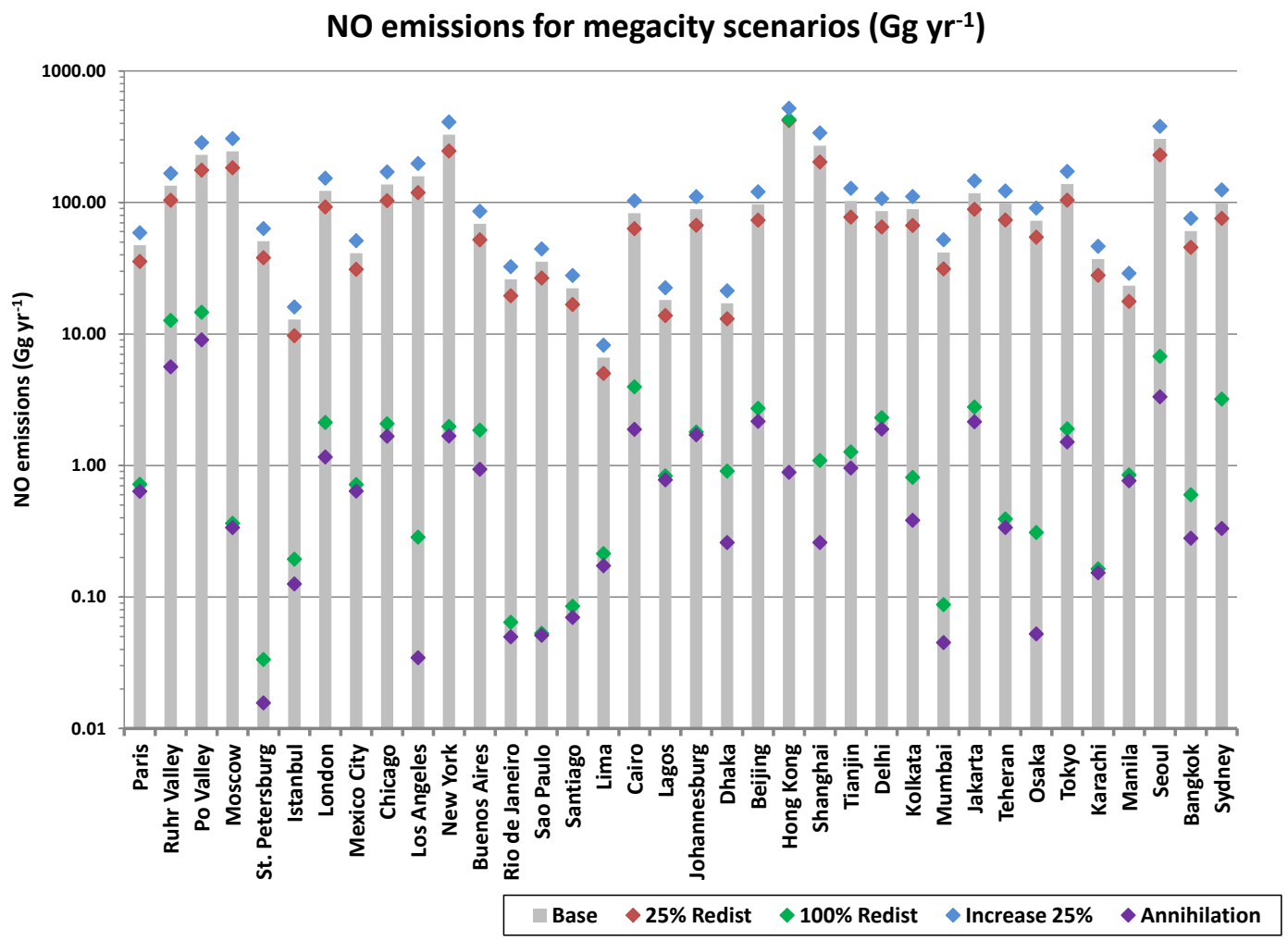

Fig. 1. NO emissions are shown in $\mathrm{Ggyr}^{-1}$ for each of the megacities in the study under different emission scenarios. Note the scale is logarithmic to show the full range of emission perturbations. The totals are calculated on a $0.5^{\circ} \times 0.5^{\circ}$ grid.

\subsection{Tagging methodology}

The method we use to tag the $\mathrm{NO}_{\mathrm{x}}$ emissions from megacities is a $\mathrm{NO}_{\mathrm{x}}-\mathrm{O}_{3}$ tagging mechanism based on the approach of Emmons et al. (2012). The tagging creates a copy of the $\mathrm{NO}_{\mathrm{x}}$ emissions from the standard chemistry, and follows the nitrogen compounds through a separate but identical chemical mechanism. Crucially, the tagging does not affect the standard chemistry. Tagged ozone is produced through the photolysis and oxidation of tagged $\mathrm{NO}_{2}$. The chemical destruction and loss of tagged ozone through deposition occurs at the same rate as non-tagged ozone is destroyed.

In UM-UKCA, the tagging scheme tracks all odd nitrogen and odd oxygen species. Tagged species react with the compounds in the standard chemistry in exactly the same way as non-tagged species but do not influence the standard chemistry. In this work we use a chemical tropopause defined as the altitude where ozone reaches $150 \mathrm{ppb}$. Globally, we find the summation of tagged ozone from all the separate $\mathrm{NO}_{\mathrm{x}}$ sources and the stratospheric ozone source is equal to $98.4 \%$ of the total tropospheric ozone. The remaining $1.6 \%$ includes ozone from minor $\mathrm{O}_{3}$-forming reactions that are not included in the tagging scheme.

\subsection{Chemical regime diagnostics}

As an additional diagnostic tool, we also consider the sensitivity of ozone production regimes to megacity emission perturbations. The ratio of VOCs to nitrogen oxides $\left(\mathrm{NO}_{\mathrm{x}}\right)$ determines the photochemistry of a region, such that highly polluted urban areas lie in a different chemical environment to that of rural regions. Megacities, as large emitters of NO, are typically characterised as lying in VOC-limited chemical regimes. The non-linearity of the ozone chemistry means that initial concentrations of $\mathrm{NO}$ are not directly proportional to the ozone formed; hence small perturbations in emissions can change the chemical environment and the ozone produced (Jenkin and Clemitshaw, 2000; Sillman, 1995, 1999). By analysing the ratio of $\mathrm{NO}_{\mathrm{x}}$ to VOCs, we can assess the chemical regime and so, for example, contrast latitudinal groups of megacities. Changes to emissions will affect the chemical conversion regimes and hence can provide insight into the likely effects of emission reduction policies.

To diagnose the typical chemical environments of megacity regions before and after the redistribution of emissions, we use the ratio of hydrogen peroxide formation to nitric acid formation as a chemical diagnostic (Sillman, 1995). A high ratio of $\mathrm{H}_{2} \mathrm{O}_{2}: \mathrm{HNO}_{3}$ indicates a $\mathrm{NO}_{\mathrm{x}}$-limited environment, whereas a low ratio indicates the regime to be more VOClimited. In some regions an ozone removal chemical regime 

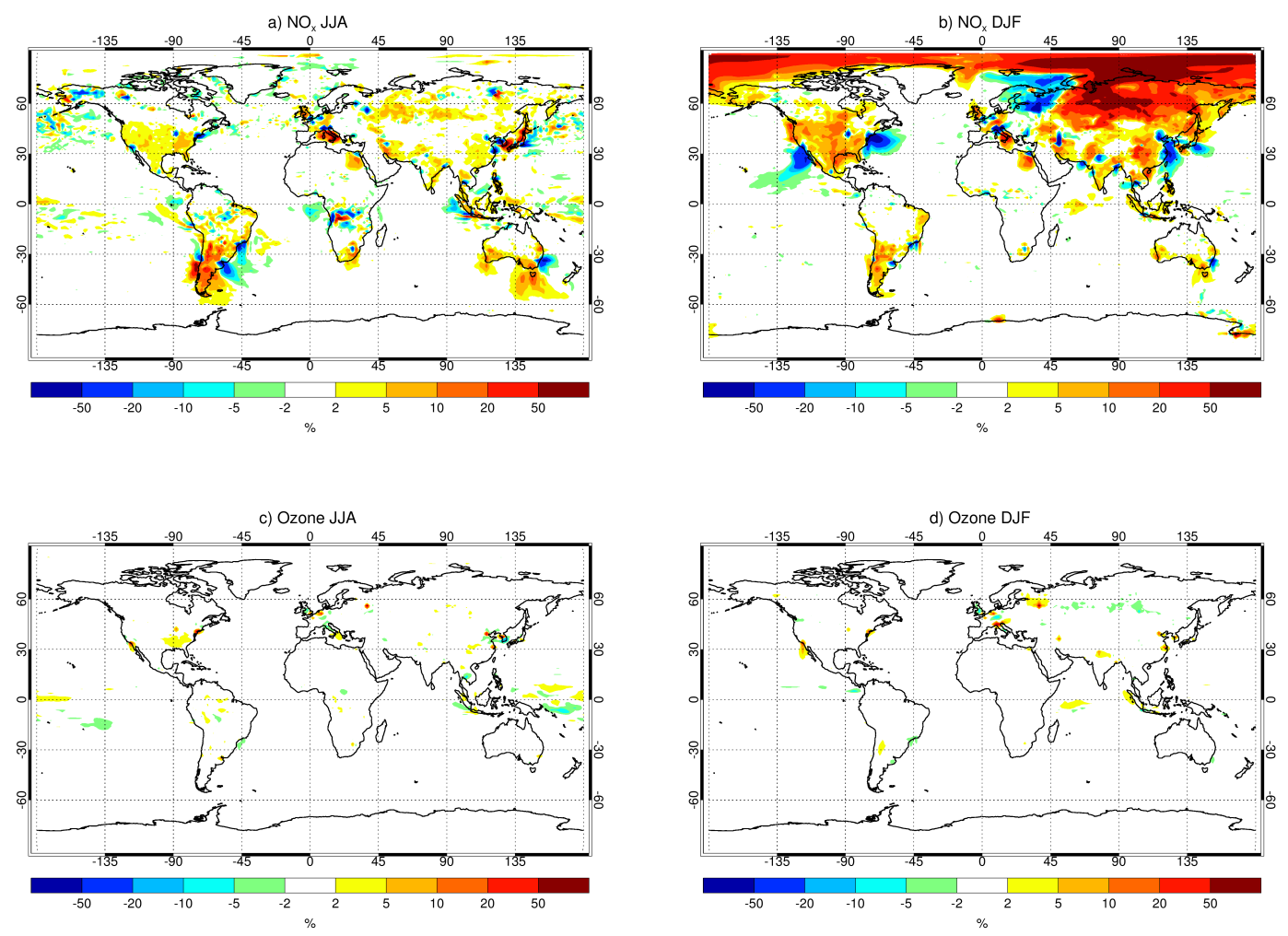

Fig. 2. Global surface differences showing the effect of redistributing $100 \%$ of megacity anthropogenic emissions compared to a control run. Seasonal mean differences are shown for JJA (left column) and DJF (right column) for $\mathrm{NO}_{\mathrm{x}}$ (top row) and ozone (bottom row). Differences are as percentage change $\left(\frac{\text { redistribution-base }}{\text { base }} \times 100\right)$.

dominates due to the titration of $\mathrm{O}_{3}$ by high $\mathrm{NO}$ concentrations. We therefore also consider the flux through the titration reaction $\mathrm{O}_{3}+\mathrm{NO} \rightarrow \mathrm{NO}_{2}+\mathrm{O}_{2}$.

\section{Modelling the effect of megacity emissions}

\subsection{Global and regional effects}

In this section we analyse surface changes in $\mathrm{NO}_{\mathrm{x}}$ and ozone for the different emission scenarios. Percentage changes are calculated as $\left(\frac{\text { scenario-base }}{\text { base }} \times 100\right)$. In the annihilation scenario the complete removal of megacity emissions, which accounts for $\sim 4.3 \%$ of the total $\mathrm{NO}_{\mathrm{x}}$, leads to a small global tropospheric column ozone decrease of $0.27 \%$, which compares to the small $0.84 \%$ change found by Butler et al. (2012). Some differences are expected due to the model differences both in the online chemistry and in lightning, soil, and isoprene emissions. However, the size of the effect supports the conclusion that megacities have a small impact on tropospheric ozone compared to their share of precursor emissions. The effect of megacity emissions on the annual global burden of $\mathrm{NO}$ and $\mathrm{NO}_{2}$ is found to be $2.24 \%$ and $2.79 \%$ for the whole troposphere and larger at the surface $(9.36 \%$ and $4.47 \%$ respectively). This shows $\mathrm{NO}_{\mathrm{x}}$ to be strongly af- fected by megacity emissions, with the increases at the surface greater than the contribution of megacities to the total $\mathrm{NO}_{\mathrm{x}}$ emissions. The effect of megacity emissions on the annual global burden of $\mathrm{OH}$ is found to be small, $-0.14 \%$ over the whole troposphere and less than $-0.1 \%$ in the surface layer.

We now focus on the results of the $100 \%$ redistribution run. This redistribution scenario is more meaningful than the megacity annihilation, as total emissions are conserved, but still provides an upper-bound case where changes are large enough to be distinguished from model noise (note that the $25 \%$ redistribution scenario shows very similar but weaker changes compared to the $100 \%$ redistribution scenario and is therefore not discussed explicitly in this section). Percentage changes of surface $\mathrm{NO}_{\mathrm{x}}$ and ozone under the $100 \%$ redistribution scenario are shown in Fig. 2 for summer and winter averages. Globally, the total annual difference in ozone between the control run and the $100 \%$ redistribution run is $0.12 \%$, although larger regional differences are seen as illustrated by changes over the European domain. The small change in total annual ozone supports the findings of both previous annihilation studies on regional and global scales (Butler and Lawrence, 2009; Butler et al., 2012) and the annihilation run carried out in this work. 

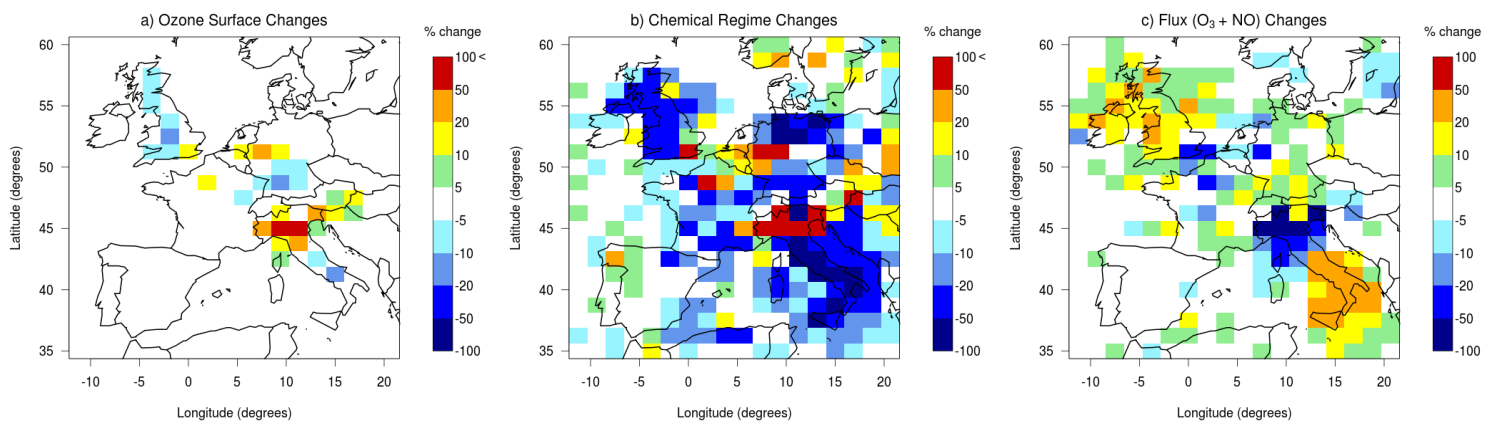

Fig. 3. Summary for Europe of the $100 \%$ redistribution run compared to the base run for the month of December. Figures show (a) ozone surface changes; (b) surface chemical regime changes through the ratio of $\mathrm{H}_{2} \mathrm{O}_{2}: \mathrm{HNO}_{3}$ production, where large positive change indicates the regime shifting towards more $\mathrm{NO}_{\mathrm{x}}$-limited conditions and large negative change indicates the regime shifting towards more VOC-limited conditions; and (c) surface changes in the removal of $\mathrm{O}_{3}$ through the reaction flux $\mathrm{O}_{3}+\mathrm{NO}$. All differences are as percentage change ( $\left.\frac{\text { redistribution-base }}{\text { base }} \times 100\right)$.

Figure 2 shows that redistributing megacities' emissions has a larger impact during winter months, particularly in $\mathrm{NO}_{\mathrm{x}}$. This is caused by the change in relative sources of $\mathrm{NO}_{\mathrm{x}}$ and photochemically generated $\mathrm{HO}_{\mathrm{x}}$ (Jacob et al., 1995; Wu et al., 2009). During winter, the longer lifetime of $\mathrm{NO}_{\mathrm{x}}$ allows for longer-range atmospheric transport. Focusing on the European region, the complete redistribution of megacity emissions reduces $\mathrm{NO}_{\mathrm{x}}$ in the megacities and increases its concentrations in surrounding areas. The largest effects are within the host countries, although horizontal and vertical advection ensure changes are not confined to country boundaries. Interestingly, although the total $\mathrm{NO}_{\mathrm{x}}$ emitted remains constant, the effect of shifting emissions away from the cities leads to a small increase in background ozone over Europe $(+0.58 \%)$. In particular, ozone is found to increase in all seasons in the megacities of London, Paris and the Ruhr Valley. This can be explained partly by a local decrease in NO with subsequent reduction in the amount of ozone directly destroyed by titration, a mechanism responsible for $\mathrm{O}_{3}$ depletion in polluted regions. Additionally, the background chemical regime in the megacities is also affected by the emission changes, and in this case it is perturbed towards a more $\mathrm{NO}_{\mathrm{x}}$-limited environment. Due to the non-linearity in the system, a more $\mathrm{NO}_{\mathrm{x}}$-limited environment leads to more efficient ozone production with the reduction in emissions (Sillman, 1999; Kleinman et al., 1994). Fluxes through reactions outlined in Sect. 2.5 were used to analyse the changes in ozone due to the redistribution scenarios. The results for the $100 \%$ redistribution scenario in winter are presented in Fig. 3. Figure 3 shows that European megacities experience increased ozone, reduced titration and a shift from a strongly VOC-limited to a weakly VOC-limited chemical regime as a result of redistributing emissions away from the megacity grid cells.

With a $25 \%$ increase in megacity emissions the global tropospheric ozone increases by $<0.13 \%$. Therefore the effect of increasing megacity emissions also leads to a dispropor- tionately small impact on tropospheric ozone compared to their share of precursor emissions, in agreement with the annihilation scenario and with the work of Butler and Lawrence (2009). Downwind of megacities there is increased ozone production as a result of the additional emissions. However, we point out that the relatively coarse model resolution of $1.875^{\circ} \times 1.25^{\circ}$ might reduce the impact of increasing emissions in megacity grid cells since the increased emissions are spread over a larger area than would be the case using a higher-resolution grid. The use of a higher-resolution chemistry-climate model would therefore be beneficial in determining more local effects.

\subsection{Local effects}

In order to assess the impact of the redistribution scenarios at the megacity grid cell scale, monthly mean ozone concentrations are compared for all cities, with results gathered into groups according to latitude and shown in Fig. 4. Each panel shows ozone percentage changes between the base run and the four scenarios. Solid lines represent the mean of all megacities in each latitude band, with the error bars reflecting $\pm 1 \sigma$. In the Northern Hemisphere, in the $100 \%$ redistribution run ozone increases in megacity grid cells by up to $30 \%$ (Fig. 4a). The annihilation and $100 \%$ redistribution scenarios have similar effects on ozone within the megacity grid cells. The tropical and Southern Hemisphere megacities see smaller changes in ozone, caused by differences in the background chemical environments, which are typically cleaner and less VOC-limited. In the $25 \%$ increase scenario we find a decrease in megacities ozone over all latitude groups, particularly in winter. The addition of $\mathrm{NO}$ emissions increases the titration of ozone within megacity grid cells and hence leads to decreases in ozone concentrations. The marked seasonal cycle in ozone for the Northern and Southern Hemisphere megacities implies that the effect of emission changes are highest in the winter months, while in the tropics the effect 

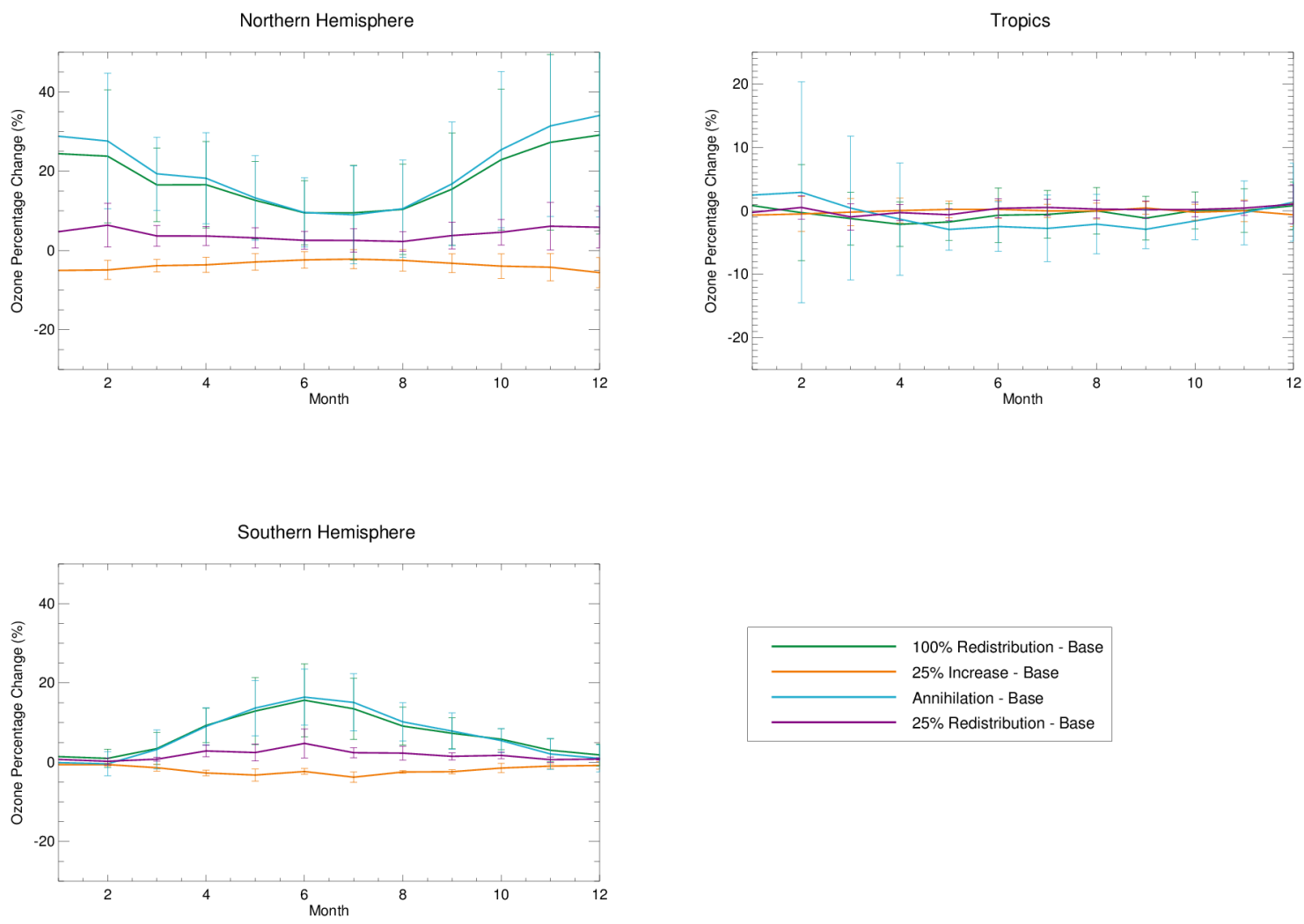

Fig. 4. Percentage change in megacity surface ozone for emission perturbation scenarios. Megacities are grouped and averaged according to latitudinal bands; Northern Hemisphere megacities are considered those that are located $>25^{\circ} \mathrm{N}$, and Southern Hemisphere megacities $>25^{\circ} \mathrm{S}$. Lines are coloured according to scenario (see key bottom right). Error bars indicate one standard deviation from the mean.

of reducing or increasing megacities' emissions has a small effect on ozone concentrations throughout the year.

\subsection{Chemical regime changes}

Figure 5a-c show the annual average $\mathrm{H}_{2} \mathrm{O}_{2}: \mathrm{HNO}_{3}$ formation ratio for each megacity, for the $25 \%$ and $100 \%$ redistribution runs and the $25 \%$ increase scenario. Fluxes are calculated as a mean over the lowest 6 model levels, i.e. up to a height of $320 \mathrm{~m}$. The figure highlights the grouping of megacities into different latitude bands (indicated by the colour of the arrow), with arrows pointing from the base run to the scenario run to show the change in ratio observed with the perturbation to the emissions. In all latitude groups, the redistribution of megacity emissions leads to a shift in chemical environment, usually from a strongly VOC-limited environment towards a more weakly VOC-limited environment. Tropical megacities are typically located in "cleaner" surrounding environments and pollutants are subject to more rapid vertical transport (Butler and Lawrence, 2009). Hence tropical megacities tend to have higher $\mathrm{H}_{2} \mathrm{O}_{2}: \mathrm{HNO}_{3}$ formation ratios.

The redistribution of anthropogenic emissions leads to a reduction in $\mathrm{NO}_{\mathrm{x}}$ available to form nitric acid, and hence the dominant loss process of $\mathrm{HO}_{\mathrm{x}}$ radicals moves toward the formation of hydroperoxides. Although both $\mathrm{NO}_{\mathrm{x}}$ and VOC concentrations change with redistribution, the shorter lifetime of $\mathrm{NO}_{\mathrm{x}}$ compared to VOCs leads to localised $\mathrm{NO}_{\mathrm{x}}$ effects and more widely distributed VOC effects. Therefore the local regime tends towards more $\mathrm{NO}_{\mathrm{x}}$-limited conditions under a redistribution scenario. The largest changes in fluxes are seen for the tropical megacities, with a large reduction in the formation of nitric acid. This is likely to be due to the high amount of natural VOCs available in these regions and lack of $\mathrm{NO}_{\mathrm{x}}$ in the surrounding environment. The $25 \%$ redistribution scenario (Fig. 5b) shows changes in the formation ratio smaller than but similar to the $100 \%$ redistribution scenario (Fig. 5a). On the other hand, the $25 \%$ increase scenario shows a reversal of the changes with an increase in the flux to nitric acid. Changes in this case are small, which can be explained by the small perturbation and the fact that the megacities are already VOC-limited.

The chemical regime is seasonally dependent, and regions can vary from more VOC-limited conditions in winter to more $\mathrm{NO}_{\mathrm{x}}$-limited conditions in summer (Jacob et al., 1995). Figure $5 \mathrm{~d}$ shows winter and summer averages for the grouped megacities. Note Hong Kong is not included in this analysis, as in the redistribution scenarios the city and country 

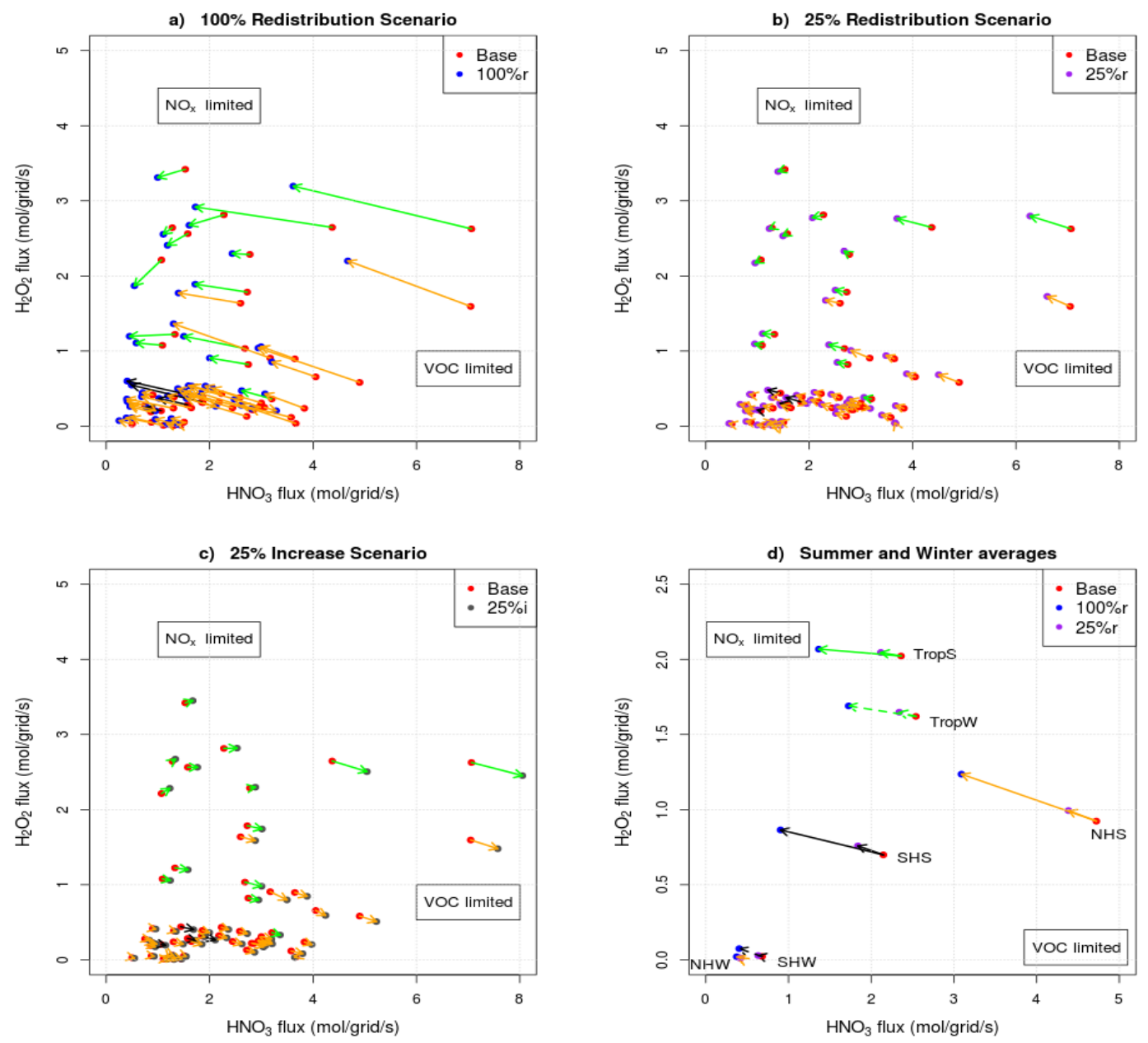

- Northern Hemisphere - Southern Hemisphere — Tropics

Fig. 5. (a-c) Annual average $\mathrm{H}_{2} \mathrm{O}_{2}: \mathrm{HNO}_{3}$ formation up to $320 \mathrm{~m}$ for individual megacity grid cells with the base ratio in red, (a) $100 \%$ redistribution in blue, (b) $25 \%$ redistribution scenario in purple and (c) $25 \%$ increase scenario in grey. Arrows link megacity grid cell changes from the base run to the scenario run. The colour of the arrow relates to latitude: orange arrows indicate Northern Hemisphere megacities, black arrows indicate Southern Hemisphere megacities and green arrows indicate megacities in the tropics. In (d) seasonal averages are shown for all megacity grid cells within the latitude band. Solid arrows represent summer changes, and dashed arrows represent winter changes. Lines are labelled as Northern Hemisphere megacities in summer (NHS) and winter (NHW), Southern Hemisphere megacities in summer (SHS) and winter (SHW) and tropical megacities in summer (TropS) and winter (TropW). Note the tropical megacity averages are plotted for boreal winter and summer.

boundaries are almost identical. In general, megacities in the summer months have a higher $\mathrm{H}_{2} \mathrm{O}_{2}: \mathrm{HNO}_{3}$ formation ratio, showing a tendency to be less VOC-limited than in the winter months. Changes in the $\mathrm{H}_{2} \mathrm{O}_{2}: \mathrm{HNO}_{3}$ formation ratio after redistribution are largest during the winter months for the extratropical megacities. These changes in ozone production regime are found to correlate with the large winter ozone changes, as megacities enter an ozone production regime after redistribution and ozone concentrations increase.

Perturbing the background chemical regime has implications for emission control strategies, with the reduction of NO not necessarily having the expected air quality benefits.
A reduction in NO may lead to an increase in the ozone exposure in megacities, as discussed in Sect. 4.1.

\subsection{Tagging megacity emissions}

The impact of megacity emissions on ozone concentrations is also studied using the tagging approach outlined in Sect. 2.4. Figure 6 shows the global annual average ratio of tagged ozone from megacity emissions to all non-tagged ozone at the surface, with a focus over European regions. Globally, the tagging of $\mathrm{NO}_{\mathrm{x}}$ emissions attributes $0.71 \%$ of total ozone to megacity emissions. The distribution of tagged ozone (left 

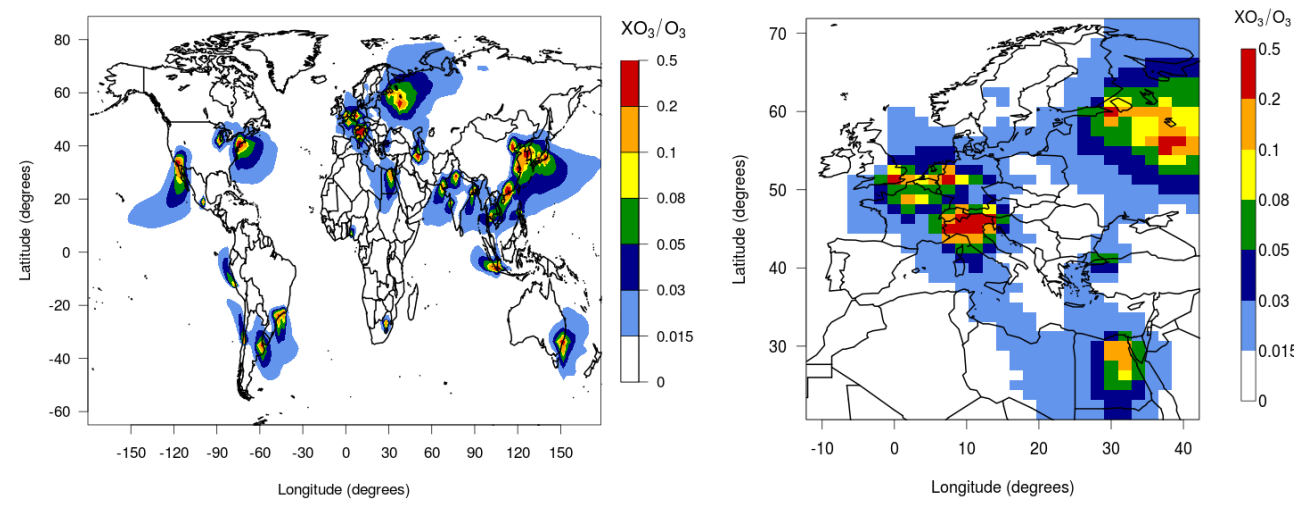

Fig. 6. Annual average ratio of tagged ozone from megacity emissions to total ozone. Surface ratio is shown both globally (left) and zoomed in over Europe (right).
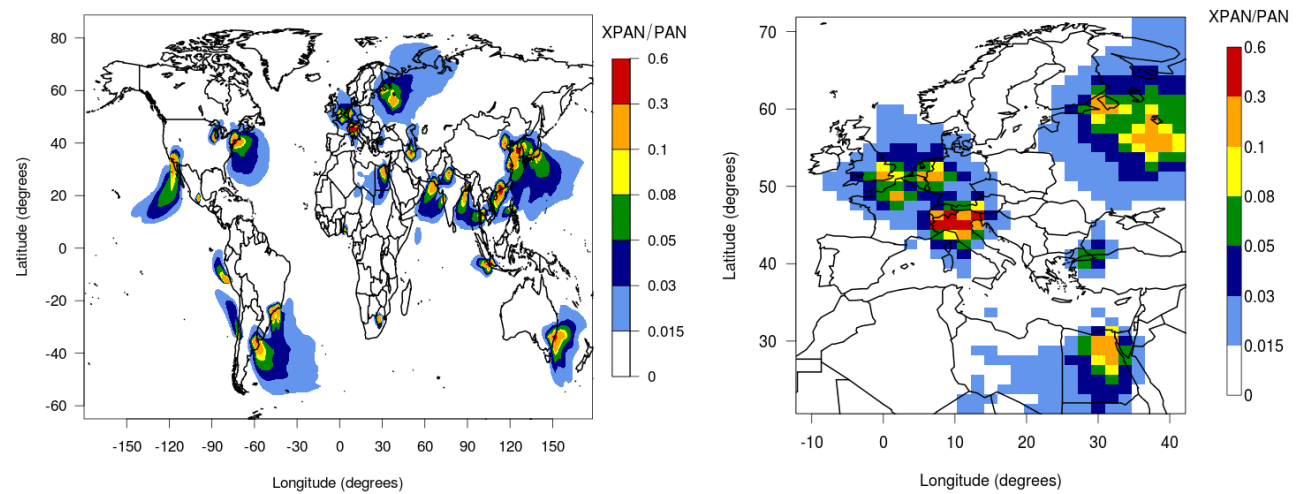

Fig. 7. Annual average ratio of tagged PAN from megacity emissions to total PAN. Surface ratio is shown both globally (left) and zoomed in over Europe (right).

panel) shows the continental-scale effect of megacity emissions. This spread is larger in winter months due to the longer atmospheric lifetime of $\mathrm{NO}_{\mathrm{x}}$ allowing for greater transport. Over continental Europe, on average $\sim 5 \%$ of the background ozone is attributed to megacity emissions (Fig. 6). Near megacities this typically increases to $20-40 \%$, although there are larger uncertainties at this scale due to the tagging scheme not accounting for all chemical species (see Sect. 2.4).

In comparing the global annual $\mathrm{O}_{\mathrm{x}}$ budget for near the surface $(<320 \mathrm{~m})$ for the full chemistry scheme, and for the tagged $\mathrm{O}_{\mathrm{x}}$ from megacities, we find the chemical production and loss of $\mathrm{O}_{\mathrm{x}}$ attributed to megacity emissions is around $\sim 1.5 \%$ of the total. Overall, the ratio of chemical production to loss is approximately the same for $\mathrm{O}_{\mathrm{x}}$ due to megacity emissions and for the full non-tagged $\mathrm{O}_{\mathrm{x}}$ budget.

The transport of ozone precursor species is important for the downwind production of ozone and hence for the effects of emissions on continental scales. PAN is known for its important role in the long-range transport of ozone (HTAP, 2010; Parrish et al., 2012). In addition, it is also a toxic component of photochemical smog. Figure 7 shows the tagged
PAN produced as a result of megacity emissions. Its lifetime depends on the ambient temperature, with its stability in the cold upper troposphere allowing it to be transported over long distances. Once it descends and undergoes thermal decomposition, the $\mathrm{NO}_{\mathrm{x}}$ produced can then form ozone, often in $\mathrm{NO}_{\mathrm{x}}$-limited regions where the ozone production efficiency is high (Wild et al., 1996). Around $0.78 \%$ of global PAN is found to be a result of megacity emissions, and over Europe the average contribution of megacities to background PAN is $\sim 2 \%$, with a maximum over the Po Valley of $\sim 54 \%$. The contribution of megacity emissions to PAN is particularly high in the Northern Hemisphere.

\subsection{Tagging versus perturbation}

In this section we discuss the merits of the two different approaches used to investigate the effect of megacity emissions and compare their results. Both approaches make differing but complementary contributions to understanding the effect of megacities. The emission perturbation method is a useful tool to investigate changes in megacity emissions. These types of experiments can provide guidance to policy-relevant questions such as what would be the impact on oxidants and 


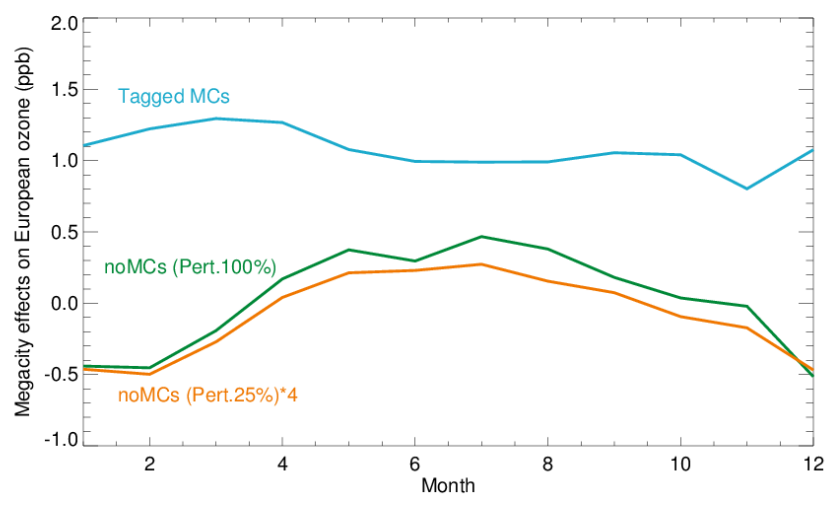

Fig. 8. European surface ozone attributed to megacity emissions as a monthly average for the tagging and perturbation techniques. An annihilation scenario and a $25 \%$ increase scenario are compared, where the $25 \%$ increase scenario is scaled to $100 \%$ for comparison purposes.

other pollutants when altering megacity emissions. In contrast, tagging techniques are best suited to separate the contribution of megacity emissions on pollutants and oxidants, relative to that of other emission sources.

In Sect. 3.1, the impact of megacities was quantified using an annihilation method, showing that removal of megacity emissions results in a $0.27 \%$ reduction of total tropospheric ozone. In contrast, the tagging approach described in Sect. 3.4 attributes $0.71 \%$ of tropospheric ozone to megacity emissions. Both methods find a contribution of less than $1 \%$, and so demonstrate a disproportionately low impact of megacities on global total ozone. Nevertheless there is an important quantitative difference in the results from the two methods.

At relatively clean-air oceanic locations, both methods similarly show megacities to have very little influence on ozone concentrations. Over polluted continental regions, such as Europe, North America and Asia, the tagging method in each region is found to attribute a greater amount of ozone to megacity emissions. Figure 8 shows a comparison of the tagging and perturbation results as a monthly time series over Europe. The perturbation results are shown for the annihilation scenario (base-annihilation) and for the $25 \%$ increase scenario $((25 \%$ increase $\times 4)$-base $)$. The scaling of the $25 \%$ increase scenario allows for direct comparison with the $100 \%$ annihilation scenario and the tagging method. Many previous emission perturbation studies used smaller perturbations (10-20\%), to reduce the effects of chemical nonlinearity (Wild and Akimoto, 2001; West et al., 2009a; Wild et al., 2012; Fiore et al., 2012). However, over the larger European domain here, the difference between the scaled $25 \%$ and $100 \%$ perturbation results is small.

In Fig. 8, the tagging method attributes a greater amount of ozone to megacities over Europe. Around $1 \mathrm{ppb}$ of surface ozone over the European domain $\left(-15-30^{\circ} \mathrm{E}, 30-60^{\circ} \mathrm{N}\right)$ is attributed to megacities through this method. In Sect. 3.3, the perturbation approach was shown to alter the background chemical environment, which in turn affects the rate of ozone production and loss and contributes to the differences we see here. Over the European domain, the rates of ozone production and loss are reduced in the perturbation run compared to the base run. Overall the lower ozone production rate leads to a net reduction in ozone over Europe when the effects of megacities are represented using the perturbation method. Additionally, the perturbation method leads to large changes in ozone production and loss rates in megacities compared to the base (up to $80 \%$ ), while the tagging method leads to much smaller changes $(<10 \%)$. This is in agreement with Emmons et al. (2012), who find larger changes in ozone production and loss rates in a perturbation method compared to a tagging method.

There are uncertainties associated with using a $\mathrm{NO}_{\mathrm{x}}$ tagging scheme for megacity studies; any production of ozone via peroxy radicals without $\mathrm{NO}_{\mathrm{x}}$ catalysts which is not accounted for in $\mathrm{NO}_{\mathrm{x}}$ tagging scheme may become significant at the local megacity scale. Therefore, although the tagging method used here is useful in global source attribution, a fulltagging scheme (i.e. also including tagged VOCs) would be beneficial for studying ozone production and loss on local scales.

\section{Megacity impacts}

The perturbation method can be used to evaluate scenarios of emission changes on ozone production and loss, without the great number of additional reactions and tracers needed in the tagging method. In these final sections, we consider some of the impacts of megacities using the redistribution scenarios.

\subsection{Ozone exceedance days}

Ozone exceedance days, defined here as days where the maximum 8-hourly average ozone concentration exceeds $60 \mathrm{ppb}$ (EU, 2008), are frequently used in air quality studies as a metric to assess the impacts of ozone exposure on the population (Anenberg et al., 2009, 2010; West et al., 2009b). Here, we output hourly data to consider changes to the daily $8 \mathrm{~h}$ maximum ozone concentrations (DM8H), caused by the perturbation of megacity emissions.

London, as a megacity in the Northern Hemisphere, sees a typical increase in ozone with the redistribution of emissions (see Sect. 3.1). The number of days exceeding the ozone DM8H $60 \mathrm{ppb}$ guideline increase if emissions are completely redistributed. Daily $8 \mathrm{~h}$ maximum ozone concentrations are found to be on average $15 \%$ higher with redistribution. London is therefore an example where the redistribution of megacity emissions increases the population exposure to high ozone concentrations. In the Northern Hemisphere, other megacities such as Los Angeles and the Ruhr 

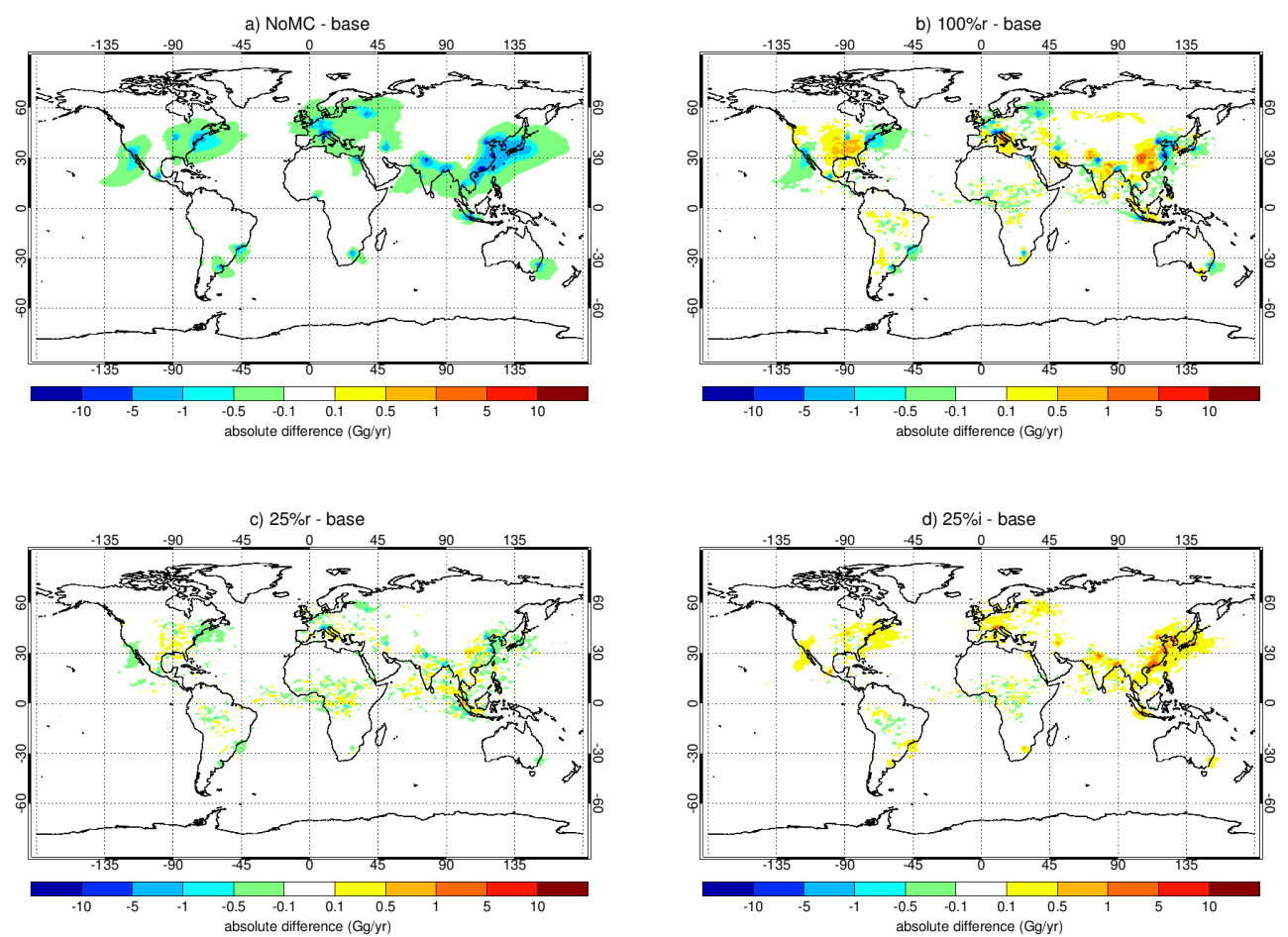

Fig. 9. Annual average changes in $\mathrm{NO}_{\mathrm{y}}$ deposition $\mathrm{Ggyr}^{-1}$ for each of the scenarios (perturbation - base). Perturbation scenarios are (a) annihilation run (label:NoMC)-base, (b) $100 \%$ redistribution run (label:100\%r)-base, (c) $25 \%$ redistribution run (label:25\%r)-base and (d) $25 \%$ increase run (label:25\%i)-base.

Valley also experience an increase in the exceedance of high ozone concentrations following redistribution. The ozone exceedances in these cases increase due to a reduction in titration with redistribution. In contrast, some tropical megacities, such as Mexico City, see a reduction in the number of ozone exceedance days with redistribution. Tropical megacities were shown in Fig. 5 to be typically in a more $\mathrm{NO}_{\mathrm{x}}$ limited chemical regime, therefore leading to a reduction in ozone exceedance days once emissions were redistributed.

Due to the coarse model grid and the ozone production biases associated with spatial averaging of the emissions, we believe a more quantitative analysis of exceedance days for specific megacities is beyond the scope of this paper. However, the link between ozone changes in Fig. 4 and ozone exceedance days allows a generalisation to be made based on latitudinal groups of megacities. After redistribution of megacity emissions, Northern Hemisphere megacities generally exceed the ozone guidelines on a greater number of days, and tropical megacities on a fewer number of days. Changes in individual cities will depend strongly on the underlying local and regional emissions (Butler et al., 2008), and on the ambient chemical environment.

\subsection{Megacity impacts on $\mathrm{NO}_{\mathrm{y}}$ deposition}

Beyond the effects of megacity emissions on air quality, the perturbation scenarios indicate that megacity emissions also have implications for the deposition of species, including nitrogen oxides $\left(\mathrm{NO}_{\mathrm{y}}=\mathrm{NO}_{\mathrm{x}}+\mathrm{HONO}+\mathrm{HNO}_{3}+\mathrm{NO}_{3}+\right.$ $\mathrm{HO}_{2} \mathrm{NO}_{2}+2 \mathrm{~N}_{2} \mathrm{O}_{5}+\mathrm{PAN}$ ). Figure 9 shows as an annual average the difference in $\mathrm{NO}_{\mathrm{y}}$ deposition in $\mathrm{Gg} \mathrm{yr}^{-1}$ for each perturbation scenario compared to the base run. The annihilation scenario (Fig. 9a) shows the effect of removing megacities is to reduce $\mathrm{NO}_{\mathrm{y}}$ deposition, not only locally in megacity areas but also regionally, especially over Europe, East Asia and parts of North America. Globally, $1.75 \mathrm{Tg} \mathrm{yr}^{-1}$ less $\mathrm{NO}_{\mathrm{y}}$ is deposited with the removal of megacity emissions $(\sim 3 \%)$. Further analysis revealed that megacity emissions contribute a higher percentage to the dry deposition of certain species; e.g. the annual average dry deposition of $\mathrm{N}_{2} \mathrm{O}_{5}$ is increased by $\sim 6 \%$ and the dry deposition of $\mathrm{HNO}_{3}$ by $\sim 4 \%$ when megacities are present. In the $100 \%$ redistribution scenario, $\mathrm{NO}_{\mathrm{y}}$ deposition is reduced in megacities and the surrounding areas. On the country scale there are regional increases in $\mathrm{NO}_{\mathrm{y}}$ deposition of up to $18 \%$; however as there is no change in the total global $\mathrm{NO}_{\mathrm{x}}$ emissions, globally the total $\mathrm{NO}_{\mathrm{y}}$ deposited changes by $<1 \%$. In the $25 \%$ redistribution scenario, the smaller perturbation means the signal is hard to distinguish above background variations. In the scenario where the emissions of megacities are increased by $25 \%, \mathrm{NO}_{\mathrm{y}}$ deposition is increased by $1 \%$ globally. Increases are particularly large in the Northern Hemisphere, with eastern Asia experiencing the greatest increases. When comparing differences 
in dry versus wet deposition, we found that globally there is little change in the ratio of dry to wet deposition with the removal of megacity emissions (less than $0.2 \%$ increase). Even on regional scales, for example over Europe, the change in ratio of dry to wet deposition is less than $0.5 \%$.

On smaller scales, both regionally and locally, the large changes in $\mathrm{NO}_{\mathrm{y}}$ deposition would be expected to have consequences for local terrestrial ecosystems. In the megacities themselves, the anthropogenic emissions affect $\mathrm{NO}_{\mathrm{y}}$ deposition. For example, in the cities of London and Paris, the complete removal of megacity emissions decreases $\mathrm{NO}_{\mathrm{y}}$ deposition by $\sim 10 \%$ and $\sim 19 \%$ respectively. The annihilation of megacity emissions leads to the greatest changes in $\mathrm{NO}_{\mathrm{y}}$ deposition in Chinese megacities, with $\mathrm{NO}_{\mathrm{y}}$ deposition in Shanghai decreasing by up to $\sim 14 \mathrm{Ggyr}^{-1}(\sim 36 \%)$. When emissions are redistributed, as in the $100 \%$ redistribution scenario, $\mathrm{NO}_{\mathrm{y}}$ deposition increases over more rural regions. For example, there are increases over natural vegetation and forests in the Pacific Northwest of America and parts of Indonesia. This could have implications for carbon storage in these regions (Holland et al., 1997).

\section{Conclusions}

The impact of megacity emissions has been investigated by both perturbation and tagging methods using the UM-UKCA global chemistry-climate model. In a comparison of the methods we show results to be broadly similar, with megacities in both cases contributing $<1 \%$ to total ozone, which in this study is disproportionately small compared to their contribution to global $\mathrm{NO}_{\mathrm{x}}$ emissions $(\sim 4.3 \%)$. The methods do differ quantitatively, with tagging attributing $0.71 \%$ and perturbation/annihilation attributing $0.27 \%$ of global total ozone to megacity emissions. The method of annihilation perturbs the background chemical environment and hence underestimates the ozone attributed to megacity emissions. Over Europe, the perturbation method attribution of ozone to megacities is a factor of 2-3 less than the tagging method, with the greatest differences noted during the winter, when megacity chemical environments are generally VOC-limited.

Megacity emissions are found to have large impacts on local/regional air quality scales, with the redistribution of megacity emissions leading to over $30 \%$ increases in ozone in the Northern Hemisphere megacities. Additionally, changing the distribution of emissions locally affects the background chemical environment. This shifts towards $\mathrm{NO}_{\mathrm{x}}-$ limited conditions in the megacities with the redistribution of emissions, which is generally more conducive to ozone production. However, fully redistributing megacity emissions leads to negligible changes on the global scale, showing the local distribution of emissions to be unimportant for chemistry-climate processes on large scales.

Changes in ozone due to megacities are found to be dependent on latitude and season. Local ozone increases in the
Northern Hemisphere megacities led to a greater number of days exceeding the EU guideline maximum 8-hourly average ozone concentration of $60 \mathrm{ppb}$ following the redistribution of emissions. In contrast, tropical megacities typically experience a reduction in ozone exceedance days with redistribution.

Perturbing megacity emissions leads to changes in $\mathrm{NO}_{\mathrm{x}}$ that are reflected over hemispheric scales, with $\sim 3 \%$ of global $\mathrm{NO}_{\mathrm{y}}$ deposition associated with megacity emissions. This indicates the importance of megacity $\mathrm{NO}_{\mathrm{x}}$ emissions on the terrestrial biosphere. The additional source of nitrogen deposition could lead to nitrogen saturation and damage to sensitive ecosystems.

To assess megacity effects on local scales, clearly a higher model resolution would be beneficial. However, these studies were run with a global resolution setup, with the aim of being able to perform multiple future simulations to better understand climate and air quality interactions. Sub-grid effects of megacities are also not included at the current climate resolution. Future work should extend the basic tagging scheme in the UM-UKCA model to consider competing $\mathrm{NO}_{\mathrm{x}}-\mathrm{VOC}$ interactions in ozone production. This approach would complement perturbation approaches for quantifying the impact of emission control policies in megacities.

Acknowledgements. The research leading to these results has received funding from the European Union's Seventh Framework Programme FP/2007-2011 within the project MEGAPOLI, under grant agreement no. 212520 . Z. S. Stock wishes to thank NERC for studentship funding. A. T. Archibald thanks Herchel Smith for funding. The authors also wish to thank members of the Cambridge UKCA team for useful discussions and comments during the preparation of this manuscript.

Edited by: C. Reeves

\section{References}

Anenberg, S., West, J., Fiore, A., Jaffe, D., Prather, M., Bergmann, D., Cuvelier, K., Dentener, F., Duncan, B., Gauss, M., Hess, P., Jonson, J., Lupu, A., MacKenzie, I., Marmer, E., Park, R., Sanderson, M., Schultz, M., Shindell, D., Szopa, S., Vivanco, M., Wild, O., and Zang, G.: Intercontinental Impacts of Ozone Pollution on Human Mortality, Environ. Sci. Technol., 43, 6482-6487, 2009.

Anenberg, S., Horowitz, L., Tong, D., and West, J.: An Estimate of the Global Burden of Anthropogenic Ozone and Fine Particulate Matter on Premature Human Mortality Using Atmospheric Modeling, Environ. Health Perspect., 118, 1189-1195, 2010.

Archibald, A., Levine, J., Abraham, N., Cooke, M., Edwards, P., Heard, D., Jenkin, M., Karunaharan, A., Pike, R., Monks, P., Shallcross, D., Telford, P., Whalley, L., and Pyle, J.: Impacts of HOx regeneration and recycling in the oxidation of isoprene: Consequences for the composition of past, present and future atmospheres, Geophys. Res. Lett., 38, L05804, doi:10.1029/2010GL046520, 2011. 
Baklanov, A., Lawrence, M., Pandis, S., Mahura, A., Finardi, S., Moussiopoulos, N., Beekmann, M., Laj, P., Gomes, L., Jaffrezo, J.-L., Borbon, A., Coll, I., Gros, V., Sciare, J., Kukkonen, J., Galmarini, S., Giorgi, F., Grimmond, S., Esau, I., Stohl, A., Denby, B., Wagner, T., Butler, T., Baltensperger, U., Builtjes, P., van den Hout, D., van der Gon, H. D., Collins, B., Schluenzen, H., Kulmala, M., Zilitinkevich, S., Sokhi, R., Friedrich, R., Theloke, J., Kummer, U., Jalkinen, L., Halenka, T., Wiedensholer, A., Pyle, J., and Rossow, W. B.: MEGAPOLI: concept of multi-scale modelling of megacity impact on air quality and climate, Adv. Sci. Res., 4, 115-120, 2010.

Bellouin, N., Boucher, O., Haywood, J., Johnson, C., Jones, A., Rae, J., and Woodward, S.: Improved representation of aerosols for HadGEM2, Tech. rep., Met Office Hadley Centre, available online at http://www.metoffice.gov.uk/media/pdf/8/f/HCTN_73. pdf, (last access: May 2013), 2007.

Berrisford, P., Dee, D., Fielding, K., Fuentes, M., Kallberg, P., Kobayashi, S., and Uppala, S.: The ERA-Interim Archive. ERA Report Series. 1. Technical Report, Tech. Rep. 16 pp., European Centre for Medium-Range Weather Forecasts, Shinfield Park, Reading, UK, 2009.

Bowman, W., Cleveland, C., Halada, L., Hresko, J., and Baron, J.: Negative impact of nitrogen deposition on soil buffering capacity, Nature Geosci., 1, 767-770, 2008.

Brown-Steiner, B. and Hess, P.: Asian influence on surface ozone in the United States: A comparison of chemistry, seasonality, and transport mechanisms, J. Geophys. Res. Atmos., 116, D17309, doi:10.1029/2011jd015846, 2011.

Butler, T. M. and Lawrence, M. G.: The influence of megacities on global atmospheric chemistry: a modelling study, Environ. Chem., 6, 219-225, 2009.

Butler, T. M., Lawrence, M. G., Gurjar, B. R., Van Aardenne, J., Schultz, M., and Lelieveld, J.: The representation of emissions from megacities in global emission inventories, Atmos. Environ., 42, 703-719, 2008.

Butler, T. M., Lawrence, M. G., Taraborrelli, D., and Lelieveld, J.: Multi-day ozone production potential of volatile organic compounds calculated with a tagging approach, Atmos. Environ., 45, 4082-4090, 2011.

Butler, T. M., Stock, Z. S., Russo, M. R., Denier van der Gon, H. A. C., and Lawrence, M. G.: Megacity ozone air quality under four alternative future scenarios, Atmos. Chem. Phys., 12, 44134428, doi:10.5194/acp-12-4413-2012, 2012.

Dall'Amico, M., Gray, L. J., Rosenlof, K. H., Scaife, A. A., Shine, K. P., and Stott, P. A.: Stratospheric temperature trends: impact of ozone variability and the QBO, Clim. Dynam., 34, 381-398, 2010.

Dee, D. P., Uppala, S. M., Simmons, A. J., Berrisford, P., Poli, P., Kobayashi, S., Andrae, U., Balmaseda, M. A., Balsamo, G., Bauer, P., Bechtold, P., Beljaars, A. C. M., van de Berg, L., Bidlot, J., Bormann, N., Delsol, C., Dragani, R., Fuentes, M., Geer, A. J., Haimberger, L., Healy, S. B., Hersbach, H., Hólm, E. V., Isaksen, L., Kållberg, P., Köhler, M., Matricardi, M., McNally, A. P., Monge-Sanz, B. M., Morcrette, J.-J., Park, B.-K., Peubey, C., de Rosnay, P., Tavolato, C., Thépaut, J.-N., and Vitart, F.: The ERA-Interim reanalysis: configuration and performance of the data assimilation system, Q. J. Roy. Meteor. Soc., 137, 553-597, 2011.
Dentener, F., Stevenson, D., Ellingsen, K., van Noije, T., Schultz, M., Amann, M., Atherton, C., Bell, N., Bergmann, D., Bey, I., Bouwman, L., Butler, T., Cofala, J., Collins, B., Drevet, J., Doherty, R., Eickhout, B., Eskes, H., Fiore, A., Gauss, M., Hauglustaine, D., Horowitz, L., Isaksen, I. S. A., Josse, B., Lawrence, M., Krol, M., Lamarque, J. F., Montanaro, V., Muller, J. F., Peuch, V. H., Pitari, G., Pyle, J., Rast, S., Rodriguez, J., Sanderson, M., Savage, N. H., Shindell, D., Strahan, S., Szopa, S., Sudo, K., Van Dingenen, R., Wild, O., and Zeng, G.: The global atmospheric environment for the next generation, Environ. Sci. Technol., 40, 3586-3594, 2006.

Derwent, R. G., Stevenson, D. S., Collins, W. J., and Johnson, C. E.: Intercontinental transport and the origins of the ozone observed at surface sites in Europe, Atmos. Environ., 38, 18911901, 2004.

Emmons, L., Hess, P., Lamarque, J., and Pfister, G.: Tagged ozone mechanism for MOZART-4, CAM-chem and other chemical transport models, Geosci. Model Dev., 5, 1531-1542, 2012.

EU: Directive 2008/50/EC of the European Parliament and of the Council of 21 May 2008 on ambient air quality and cleaner air for Europe, Tech. Rep. OJ L 152, European Parliament, Council, available online at: http://ec.europa.eu/environment/air/quality/ legislation/ (last access: May 2013), 2008.

Fiore, A., Dentener, F., Wild, O., Cuvelier, C., Schultz, M., Hess, P., Textor, C., Schulz, M., Doherty, R., Horowitz, L., MacKenzie, I., Sanderson, M., Shindell, D., Stevenson, D., Szopa, S., Van Dingenen, R., Zeng, G., Atherton, C., Bergmann, D., Bey, I., Carmichael, G., Collins, W., Duncan, B., Faluvegi, G., Folberth, G., Gauss, M., Gong, S., Hauglustaine, D., Holloway, T., Isaksen, I., Jacob, D., Jonson, J., Kaminski, J., Keating, T., Lupu, A., Marmer, E., Montanaro, V., Park, R., Pitari, G., Pringle, K., Pyle, J., Schroeder, S., Vivanco, M., Wind, P., Wojcik, G., Wu, S., and Zuber, A.: Multimodel estimates of intercontinental sourcereceptor relationships for ozone pollution, J. Geophys. Res. Atmos., 114, D04301, doi:10.1029/2008JD010816, 2009.

Fiore, A. M., Naik, V., Spracklen, D. V., Steiner, A., Unger, N., Prather, M., Bergmann, D., Cameron-Smith, P. J., Cionni, I., Collins, W. J., Dalsoren, S., Eyring, V., Folberth, G. A., Ginoux, P., Horowitz, L. W., Josse, B., Lamarque, J. F., MacKenzie, I. A., Nagashima, T., O’Connor, F. M., Righi, M., Rumbold, S. T., Shindell, D. T., Skeie, R. B., Sudo, K., Szopa, S., Takemura, T., and Zeng, G.: Global air quality and climate, Chem. Soc. Rev., 41, 6663-6683, 2012.

Folberth, G. A., Rumbold, S. T., Collins, W. J., and Butler, T. M.: Global radiative forcing and megacities, Urban Climate, 1, 4 19, doi:10.1016/j.uclim.2012.08.001, 2012.

Giannakopoulos, C., Chipperfield, T., Law, K., and Pyle, J.: Validation and intercomparison of wet and dry deposition schemes using $\mathrm{Pb}-210$ in a global three-dimensional off-line chemical transport model, J. Geophys. Res. Atmos., 104, 23761-23784, doi:10.1029/1999JD900392, 1999.

Granier, C., Guenther, A., Lamarque, J., Mieville, A., Muller, J., Olivier, J., Orlando, J., Peters, J., Petron, G., Tyndall, G., and Wallens, S.: POET, a database of surface emissions of ozone precursors, available on internet at http://www.pole-ether.fr/eccad (last access: May 2013), 2005.

Grewe, V.: Technical Note: A diagnostic for ozone contributions of various $\mathrm{NO}_{\mathrm{x}}$ emissions in multi-decadal chemistry- 
climate model simulations, Atmos. Chem. Phys., 4, 729-736, doi:10.5194/acp-4-729-2004, 2004.

Grewe, V., Tsati, E., and Hoor, P.: On the attribution of contributions of atmospheric trace gases to emissions in atmospheric model applications, Geosci. Model Dev., 3, 487-499, doi:10.5194/gmd3-487-2010, 2010.

Grewe, V., Dahlmann, K., Matthes, S., and Steinbrecht, W.: Attributing ozone to $\mathrm{NO}_{\mathrm{x}}$ emissions: Implications for climate mitigation measures, Atmos. Environ., 59, 102-107, 2012.

Gurjar, B. R., Butler, T. M., Lawrence, M. G., and Lelieveld, J.: Evaluation of emissions and air quality in megacities, Atmos. Environ., 42, 1593-1606, 2008.

Gurjar, B. R., Jain, A., Sharma, A., Agarwal, A., Gupta, P., Nagpure, A. S., and Lelieveld, J.: Human health risks in megacities due to air pollution, Atmos. Environ., 44, 4606-4613, 2010.

Harpercollins Reference: Collins World Atlas, ISBN:9780007269655, 2008.

Hewitt, H. T., Copsey, D., Culverwell, I. D., Harris, C. M., Hill, R. S. R., Keen, A. B., McLaren, A. J., and Hunke, E. C.: Design and implementation of the infrastructure of HadGEM3: the nextgeneration Met Office climate modelling system, Geosci. Model Dev., 4, 223-253, doi:10.5194/gmd-4-223-2011, 2011.

Holland, E., Braswell, B., Lamarque, J., Townsend, A., Sulzman, J., Muller, J., Dentener, F., Brasseur, G., Levy, H., Penner, J., and Roelofs, G.: Variations in the predicted spatial distribution of atmospheric nitrogen deposition and their impact on carbon uptake by terrestrial ecosystems, J. Geophys. Res. Atmos., 102, 15 849-15 866, 1997.

HTAP: Hemispheric Transport of Air Pollution 2010, Part A: Ozone and Particulate Matter, Air Pollution Studies No.17, Tech. rep., United Nations, New York and Geneva, edited by: Dentener F., Keating T., and Akimoto H., 2010.

Jacob, D. J., Horowitz, L. W., Munger, J. W., Heikes, B. G., Dickerson, R. R., Artz, R. S., and Keene, W. C.: Seasonal transition from NOx- to hydrocarbon-limited conditions for ozone production over the eastern United States in September, J. Geophys. Res. Atmos., 100, 9315-9324, doi:10.1029/94JD03125, 1995.

Jenkin, M. E. and Clemitshaw, K. C.: Ozone and other secondary photochemical pollutants: chemical processes governing their formation in the planetary boundary layer, Atmos. Environ., 34, 2499-2527, 2000.

Jones, A., Roberts, D. L., Woodage, M. J., and Johnson, C. E.: Indirect sulphate aerosol forcing in a climate model with an interactive sulphur cycle, J. Geophys. Res. Atmos., 106, 20293-20310, 2001.

Kleinman, L., Lee, Y.-N., Springston, S. R., Nunnermacker, L., Zhou, X., Brown, R., Hallock, K., Klotz, P., Leahy, D., Lee, J. H., and Newman, L.: Ozone formation at a rural site in the southeastern United States, J. Geophys. Res. Atmos., 99, 3469-3482, 1994.

Lamarque, J. F., Kiehl, J. T., Brasseur, G. P., Butler, T., CameronSmith, P., Collins, W. D., Collins, W. J., Granier, C., Hauglustaine, D., Hess, P. G., Holland, E. A., Horowitz, L., Lawrence, M. G., McKenna, D., Merilees, P., Prather, M. J., Rasch, P. J., Rotman, D., Shindell, D., and Thornton, P.: Assessing future nitrogen deposition and carbon cycle feedback using a multimodel approach: Analysis of nitrogen deposition, J. Geophys. Res. Atmos., 110, D19303, doi:10.1029/2005JD005825, 2005.
Lamarque, J.-F., Bond, T. C., Eyring, V., Granier, C., Heil, A., Klimont, Z., Lee, D., Liousse, C., Mieville, A., Owen, B., Schultz, M. G., Shindell, D., Smith, S. J., Stehfest, E., Van Aardenne, J., Cooper, O. R., Kainuma, M., Mahowald, N., McConnell, J. R., Naik, V., Riahi, K., and van Vuuren, D. P.: Historical (1850-2000) gridded anthropogenic and biomass burning emissions of reactive gases and aerosols: methodology and application, Atmos. Chem. Phys., 10, 7017-7039, doi:10.5194/acp10-7017-2010, 2010.

Law, K. and Pyle, J.: Modeling trace gas budgets in the troposphere .1. Ozone and odd nitrogen, J. Geophys. Res. Atmos., 98, 1837718400, 1993a.

Law, K. and Pyle, J.: Modeling trace gas budgets in the troposphere .2. CH4 and CO, J. Geophys. Res. Atmos., 98, 18401-18412, $1993 b$.

Lawrence, M. G., Butler, T. M., Steinkamp, J., Gurjar, B. R., and Lelieveld, J.: Regional pollution potentials of megacities and other major population centers, Atmos. Chem. Phys., 7, 39693987, doi:10.5194/acp-7-3969-2010, 2007.

Logan, J. A.: An analysis of ozonesonde data for the troposphere: Recommendations for testing 3-D models and development of a gridded climatology for tropospheric ozone, J. Geophys. Res. Atmos., 104, 16115-16149, 1999.

Mayer, M., Wang, C., Webster, M., and Prinn, R. G.: Linking local air pollution to global chemistry and climate, J. Geophys. Res. Atmos., 105, 22869-22896, 2000.

Molina, M. J. and Molina, L. T.: Megacities and atmospheric pollution, J. Air Waste Manage. Assoc., 54, 644-680, 2004.

Neu, J. L., Prather, M. J., and Penner, J. E.: Global atmospheric chemistry: Integrating over fractional cloud cover, J. Geophys. Res. Atmos., 112, D11306, doi:10.1029/2006JD008007, 2007.

O'Connor, F. M., Johnson, C. E., Morgenstern, O., Abraham, N. L., Braesicke, P., Dalvi, M., Folberth, G. A., Sanderson, M. G., Telford, P. J., Young, P. J., Zeng, G., Collins, W. J., and Pyle, J. A.: Evaluation of the new UKCA climate-composition model Part 2: The Troposphere, Geosci. Model Dev. Discuss., 6, 17431857, doi:10.5194/gmdd-6-1743-2013, 2013.

Olivier, J., Peters, J., Granier, C., Petron, G., Muller, J., and Wallens, S.: Present and future surface emissions of atmospheric compounds, POET report 2, EU project EVK2-1999-00011, 2003.

Parrish, D. D., Singh, H. B., Molina, L., and Madronich, S.: Air quality progress in North American megacities: A review, Atmos. Environ., 45, 7015-7025, 2011.

Parrish, D. D., Law, K. S., Staehelin, J., Derwent, R., Cooper, O. R., Tanimoto, H., Volz-Thomas, A., Gilge, S., Scheel, H. E., Steinbacher, M., and Chan, E.: Long-term changes in lower tropospheric baseline ozone concentrations at northern mid-latitudes, Atmos. Chem. Phys., 12, 11485-11504, doi:10.5194/acp-1211485-2012, 2012.

Pfister, G. G., Emmons, L. K., Hess, P. G., Honrath, R., Lamarque, J.-F., Val Martin, M., Owen, R. C., Avery, M. A., Browell, E. V., Holloway, J. S., Nedelec, P., Purvis, R., Ryerson, T. B., Sachse, G. W., and Schlager, H.: Ozone production from the 2004 North American boreal fires, J. Geophys. Res. Atmos., 111, D24S07, doi:10.1029/2006JD007695, 2006.

Pfister, G. G., Emmons, L. K., Hess, P. G., Lamarque, J. F., Orlando, J. J., Walters, S., Guenther, A., Palmer, P. I., and Lawrence, P. J.: Contribution of isoprene to chemical budgets: A model tracer 
study with the NCAR CTM MOZART-4, J. Geophys. Res. Atmos., 113, D05308, doi:10.1029/2007JD008948, 2008.

Pöschl, U., von Kuhlmann, R., Poisson, N., and Crutzen, P.: Development and Intercomparison of Condensed Isoprene Oxidation Mechanisms for Global Atmospheric Modeling, J. Atmos. Chem., 37, 29-52, 2000.

Riahi, K., Rao, S., Krey, V., Cho, C., Chirkov, V., Fischer, G., Kindermann, G., Nakicenovic, N., and Rafaj, P.: RCP 8.5-A scenario of comparatively high greenhouse gas emissions, Clim. Change, 109, 33-57, doi:10.1007/s10584-011-0149-y, 2011.

Sanderson, M., Dentener, F., Fiore, A., Cuvelier, C., Keating, T., Zuber, A., Atherton, C., Bergmann, D., Diehl, T., Doherty, R., Duncan, B., Hess, P., Horowitz, L., Jacob, D., Jonson, J., Kaminski, J., Lupu, A., MacKenzie, I., Mancini, E., Marmer, E., Park, R., Pitari, G., Prather, M., Pringle, K., Schroeder, S., Schultz, M., Shindell, D., Szopa, S., Wild, O., and Wind, P.: A multi-model study of the hemispheric transport and deposition of oxidised nitrogen, Geophys. Res. Lett., 35, L17815, doi:10.1029/2008GL035389, 2008.

Sillman, S.: The use of $\mathrm{NO}_{y}, \mathrm{H}_{2} \mathrm{O}_{2}$, and $\mathrm{HNO}_{3}$ as indicators for ozone- $\mathrm{NO}_{\mathrm{x}}$-hydrocarbon sensitivity in urban locations, J. Geophys. Res. Atmos., 100, 14175-14188, 1995.

Sillman, S.: The relation between ozone, NOx and hydrocarbons in urban and polluted rural environments, Atmos. Environ., 33, 1821-1845, 1999.

Stevenson, D. S., Dentener, F. J., Schultz, M. G., Ellingsen, K., van Noije, T. P. C., Wild, O., Zeng, G., Amann, M., Atherton, C. S., Bell, N., Bergmann, D. J., Bey, I., Butler, T., Cofala, J., Collins, W. J., Derwent, R. G., Doherty, R. M., Drevet, J., Eskes, H. J., Fiore, A. M., Gauss, M., Hauglustaine, D. A., Horowitz, L. W., Isaksen, I. S. A., Krol, M. C., Lamarque, J. F., Lawrence, M. G., Montanaro, V., Muller, J. F., Pitari, G., Prather, M. J., Pyle, J. A., Rast, S., Rodriguez, J. M., Sanderson, M. G., Savage, N. H., Shindell, D. T., Strahan, S. E., Sudo, K., and Szopa, S.: Multimodel ensemble simulations of present-day and near-future tropospheric ozone, J. Geophys. Res. Atmos., 111, D08301, doi:10.1029/2005JD006338, 2006.

Streets, D. and Waldhoff, S.: Present and future emissions of air pollutants in China: $\mathrm{SO}_{2}, \mathrm{NO}_{\mathrm{x}}$, and $\mathrm{CO}$, Atmos. Environ., 34, 363-374, 2000.

Telford, P. J., Braesicke, P., Morgenstern, O., and Pyle, J. A.: Technical Note: Description and assessment of a nudged version of the new dynamics Unified Model, Atmos. Chem. Phys., 8, 17011712, doi:10.5194/acp-8-1701-2008, 2008.

Telford, P., Lathiere, J., Abraham, N., Archibald, A., Braesicke, P., Johnson, C., Morgenstern, O., O'Connor, F., Pike, R., Wild, O., Young, P., Beerling, D., Hewitt, C., and Pyle, J.: Effects of climate-induced changes in isoprene emissions after the eruption of Mount Pinatubo, Atmos. Chem. Phys., 10, 7117-7125, doi:10.5194/acp-10-7117-2010, 2010.

Telford, P. J., Abraham, N. L., Archibald, A. T., Braesicke, P., Dalvi, M., Morgenstern, O., O'Connor, F. M., Richards, N. A. D., and Pyle, J. A.: Implementation of the Fast-JX Photolysis scheme (v6.4) into the UKCA component of the MetUM chemistry-climate model (v7.3), Geosci. Model Dev., 6, 161177, doi:10.5194/gmd-6-161-2013, 2013.

Thompson, A. M., Witte, J. C., McPeters, R. D., Oltmans, S. J., Schmidlin, F. J., Logan, J. A., Fujiwara, M., Kirchhoff, V., Posny, F., Coetzee, G. J. R., Hoegger, B., Kawakami, S., Ogawa, T.,
Johnson, B. J., Vomel, H., and Labow, G.: Southern Hemisphere Additional Ozonesondes (SHADOZ) 1998-2000 tropical ozone climatology - 1. Comparison with Total Ozone Mapping Spectrometer (TOMS) and ground-based measurements, J. Geophys. Res. Atmos., 108, 8238, doi:10.1029/2001JD000967, 2003.

Thompson, A. M., Witte, J. C., Oltmans, S. J., Schmidlin, F. J., Logan, J. A., Fujiwara, M., Kirchhoff, V., Posny, F., Coetzee, G. J. R., Hoegger, B., Kawakami, S. J., Ogawa, T., Fortuin, J. P. F., and Kelder, H. M.: Southern Hemisphere Additional Ozonesondes (SHADOZ) 1998-2000 tropical ozone climatology - 2. Tropospheric variability and the zonal wave-one, J. Geophys. Res. Atmos., 108, 8241, doi:10.1029/2002JD002241, 2003.

van $\operatorname{der}$ A, R., Eskes, H., Boersma, K., van Noije, T., Van Roozendael, M., De Smedt, I., Peters, D., and Meijer, E.: Trends, seasonal variability and dominant $\mathrm{NO}_{\mathrm{x}}$ source derived from a ten year record of $\mathrm{NO}_{2}$ measured from space, J. Geophys. Res. Atmos., 113, D04302, doi:10.1029/2007JD009021, 2008.

van der Werf, G. R., Randerson, J. T., Giglio, L., Collatz, G. J., Mu, M., Kasibhatla, P. S., Morton, D. C., DeFries, R. S., Jin, Y., and van Leeuwen, T. T.: Global fire emissions and the contribution of deforestation, savanna, forest, agricultural, and peat fires (19972009), Atmos. Chem. Phys., 10, 11707-11735, doi:10.5194/acp10-11707-2010, 2010.

Warneke, C., de Gouw, J. A., Holloway, J. S., Peischl, J., Ryerson, T. B., Atlas, E., Blake, D., Trainer, M., and Parrish, D. D.: Multiyear trends in volatile organic compounds in Los Angeles, California: Five decades of decreasing emissions, J. Geophys. Res. Atmos., 117, D00V17, doi:10.1029/2012JD017899, 2012.

West, J., Naik, V., Horowitz, L., and Fiore, A.: Effect of regional precursor emission controls on long-range ozone transport - Part 1: Short-term changes in ozone air quality, Atmos. Chem. Phys., 9, 6077-6093, doi:10.5194/acp-9-6077-2009, 2009a.

West, J., Naik, V., Horowitz, L., and Fiore, A.: Effect of regional precursor emission controls on long-range ozone transport - Part 2: Steady-state changes in ozone air quality and impacts on human mortality, Atmos. Chem. Phys., 9, 6095-6107, doi:10.5194/acp-9-6095-2009, 2009b.

Wild, O. and Akimoto, H.: Intercontinental transport of ozone and its precursors in a three-dimensional global CTM, J. Geophys. Res. Atmos., 106, 27729-27744, 2001.

Wild, O., Law, K. S., McKenna, D. S., Bandy, B. J., Penkett, S. A., and Pyle, J. A.: Photochemical trajectory modeling studies of the North Atlantic region during August 1993, J. Geophys. Res. Atmos., 101, 29269-29288, 1996.

Wild, O., Fiore, A. M., Shindell, D. T., Doherty, R. M., Collins, W. J., Dentener, F. J., Schultz, M. G., Gong, S., MacKenzie, I. A., Zeng, G., Hess, P., Duncan, B. N., Bergmann, D. J., Szopa, S., Jonson, J. E., Keating, T. J., and Zuber, A.: Modelling future changes in surface ozone: a parameterized approach, Atmos. Chem. Phys., 12, 2037-2054, doi:10.5194/acp-12-20372012, 2012.

Wu, S., Duncan, B., Jacob, D., Fiore, A., and Wild, O.: Chemical nonlinearities in relating intercontinental ozone pollution to anthropogenic emissions, Geophys. Res. Lett., 36, L05806, doi:10.1029/2008GL036607, 2009.

Zeng, G. and Pyle, J.: Changes in tropospheric ozone between 2000 and 2100 modeled in a chemistry-climate model, Geophys. Res. Lett., 30, 1392, doi:10.1029/2002GL016708, 7, 2003. 
Zhang, L., Jacob, D. J., Knipping, E. M., Kumar, N., Munger, J. W., Carouge, C. C., van Donkelaar, A., Wang, Y. X., and Chen, D.: Nitrogen deposition to the United States: distribution, sources, and processes, Atmos. Chem. Phys., 12, 4539-4554, doi:10.5194/acp-12-4539-2012, 2012. 